\title{
Human cell receptors: potential drug targets to combat COVID-19
}

\author{
Pawan Kumar Raghav ${ }^{1}$ (1) $\cdot$ Keerthana Kalyanaraman ${ }^{2} \cdot$ Dinesh Kumar $^{3}$ \\ Received: 26 September 2020 / Accepted: 21 April 2021 / Published online: 5 May 2021 \\ (c) The Author(s), under exclusive licence to Springer-Verlag GmbH Austria, part of Springer Nature 2021
}

\begin{abstract}
Severe acute respiratory syndrome coronavirus 2 (SARS-CoV-2) causes the coronavirus disease 2019 (COVID-19). The World Health Organization (WHO) has announced that COVID-19 is a pandemic having a higher spread rate rather than the mortality. Identification of a potential approach or therapy against COVID-19 is still under consideration. Therefore, it is essential to have an insight into SARS-CoV-2, its interacting partner, and domains for an effective treatment. The present study is divided into three main categories, including SARS-CoV-2 prominent receptor and its expression levels, other interacting partners, and their binding domains. The first section focuses primarily on coronaviruses' general aspects (SARSCoV-2, SARS-CoV, and the Middle East Respiratory Syndrome Coronaviruses (MERS-CoV)) their structures, similarities, and mode of infections. The second section discusses the host receptors which includes the human targets of coronaviruses like dipeptidyl peptidase 4 (DPP4), CD147, CD209L, Angiotensin-Converting Enzyme 2 (ACE2), and other miscellaneous targets (type-II transmembrane serine proteases (TTSPs), furin, trypsin, cathepsins, thermolysin, elastase, phosphatidylinositol 3-phosphate 5-kinase, two-pore segment channel, and epithelium sodium channel C- $\alpha$ subunit). The human cell receptor, ACE2 plays an essential role in the Renin-Angiotensin system (RAS) pathway and COVID-19. Thus, this section also discusses the ACE2 expression and risk of COVID-19 infectivity in various organs and tissues such as the liver, lungs, intestine, heart, and reproductive system in the human body. Absence of ACE2 protein expression in immune cells could be used for limiting the SARS-CoV-2 infection. The third section covers the current available approaches for COVID-19 treatment. Overall, this review focuses on the critical role of human cell receptors involved in coronavirus pathogenesis, which would likely be used in designing target-specific drugs to combat COVID-19.
\end{abstract}

Keywords COVID- $19 \cdot$ Coronavirus $\cdot$ SARS-CoV $\cdot$ SARS-CoV-2 $\cdot$ ACE2 $\cdot$ WHO

\section{Abbreviations}

$3 C L^{\text {pro }} \quad 3 \mathrm{C}$ like protease

ACE2 Angiotensin converting enzyme 2

ACEi

ADAM17

ALI

Ang

Handling editor: M. S. Palma.

Pawan Kumar Raghav

pwnrghv@gmail.com

$\triangle$ Dinesh Kumar

kdinesh777@gmail.com

New Delhi, India

2 Amity Institute of Biotechnology, Amity University,

Sector-125, Noida, Uttar Pradesh, India

3 ICMR-National Institute of Cancer Prevention \& Research, Noida 201301, India
ARB Angiotensin type 1 Receptor Blocker

ARDS Acute respiratory distress syndrome

ASL Airway surface liquid

AT1 Alveolar type 1

$\mathrm{AT}_{1} \mathrm{R} \quad$ Angiotensin type 1 receptor

AT2 Alveolar type 2

$\mathrm{AT}_{2} \mathrm{R} \quad$ Angiotensin type 2 receptor

$\mathrm{B}^{0} \mathrm{AT} 1 \quad$ Sodium-dependent neutral amino acid transporter

CFTR Cystic fibrosis transmembrane conductance regulator

$\mathrm{CoV} \quad$ Coronavirus

COVID-19 Coronavirus disease 19

CVD Cardiovascular disease

DPP4 Dipeptidyl peptidase 4

E Envelope

EMMPRIN Extracellular Matrix Metalloproteinase Inducer

ENaC Epithelium sodium channel C- $\alpha$ subunit 


$\begin{array}{llll}\text { eNOS } & \text { Endothelial nitric oxide synthase } & \text { SOD } & \text { Superoxide dismutase } \\ \text { ERGIC } & \text { Endoplasmic Reticulum-Golgi Intermediate } & \text { TIMP } & \text { Tissue inhibitors of metalloproteinases } \\ & \text { Complex } & \text { TMEM16A } & \text { Transmembrane member 16 A } \\ \text { EST } & \text { Trans-epoxysuccinyl-L-leucylamindo3- } & \text { TMPRSS } & \text { Transmembrane Protease serine subfamily } \\ & \text { methylbutane ethyl ester } & \text { TNF } & \text { Tumor Necrosis Factor } \\ \text { GCSF } & \text { Granulocyte colony-stimulating factor } & \text { TPC2 } & \text { Two pore segment channel } \\ \text { GI } & \text { Gastrointestinal } & \text { TTSPs } & \text { Type 2 transmembrane serine proteases } \\ \text { GMP } & \text { Good manufacturing practice } & \text { uMSC } & \text { Umbilical cord derived MSC } \\ \text { GPCR } & \text { G-protein coupled receptor } & \text { VSV } & \text { Vesicular stomatitis virus } \\ \text { GSH } & \text { Glutathione } & \text { WHO } & \text { World Health Organization } \\ \text { GSSG } & \text { Oxidized glutathione } & \text { WT } & \text { Wild type }\end{array}$

\section{Introduction}

The novel disease COVID-19 caused by SARS-CoV-2 has recently been announced pandemic by WHO (Xu et al. 2020). The virus has been spreading with epidemic features from Wuhan of China to other Asian countries, with cases now reported worldwide (Petrosillo et al. 2020). Initially, the virus was represented as 2019-nCoV. Later, on February 12th, 2020, ICTV (International Committee on Taxonomy of Viruses) formally named it SARS-CoV-2. Initially called disease-X, it was later named COVID-19 by WHO (Liu et al. 2020a). Although the casualty rate of COVID-19 is $2.3 \%$, which is lesser than the SARS-CoV infection that causes SARS (9.5\%), and much lower than the MERS-CoV infection that causes MERS (34.4\%), while its clinical features are more related to SARS (Petrosillo et al. 2020, 2020). Phylogenetically, the SARS-CoV-2 is more closely related to SARS-CoV (sequence identity 79\%) than to MERS-CoV (sequence identity 50\%) (Kim et al. 2020; $\mathrm{Lu}$ et al. 2020). Both SARS-CoV-2 and SARS-CoV bind to a common human cell receptor, angiotensin-converting enzyme 2 (ACE2), causing their entry into host cell, but MERS-CoV is penetrated by dipeptidyl peptidase 4 (DPP4) or CD26 (Xu et al. 2020; Kim et al. 2020; Zhou et al. 2020a). SARS-CoV-2 infected patients with comorbidities like cardiovascular disease (CVD), hypertension, and diabetes are prone to severe conditions that are fatal (Hanff et al. 2020). Infectivity is provoked when spike protein (S-protein) of SARS-CoV-2 binds to the ACE2 receptor (Walls et al. 2020). Abundant expression of ACE 2 was observed in the heart, kidneys, lungs, testis, and gastrointestinal (GI) tract and carried out essential functions in several cells signaling pathways (Turner et al. 2004; Chen et al. 2020). The overexpression of ACE2 facilitates SARS-CoV-2 pathogenicity, entry, and replication (Zheng et al. 2020). Prolonged infection causes Angiotensin (Ang) II/ACE2 regulation imbalance leading to respiratory disease distress and hypoxemia in the lungs, causing Acute Respiratory Distress Syndrome (ARDS), septic shock, metabolic acidosis, and fatality (Peiris et al. 2003; Chen et al. 1998). This severe infection in the 
lungs of COVID-19 patients stimulates a drastic elevation of cytokines like interleukins (IL), (IL-2, IL-6, and IL-7), granulocyte colony-stimulating factor (GCSF), $\gamma$-induced protein 10 (IP10), monocyte chemoattractant protein 1 (MCP1), macrophage inflammatory protein 1A (MIP1A), and tumor Necrosis Factor (TNF)- $\alpha$. Primarily, the level of IL-6 was found very high in COVID-19 patients (Aghai et al. 2007), though this cytokines storm also gets provoked in severe cases of pneumonia (Huang et al. 2020). The cardiovascular system may lead to a cellular inflammatory effect, migration of vascular smooth muscle and endothelial cells, oxidative stress, and might cause atherosclerosis (Xu et al. 2020; Chen et al. 1998). The current study focuses on the prominent expression of ACE2 in various human body tissues that may correspond to infection risk. The genetic and protein expression rate of ACE2 is not constant and differs among cells, tissues, and organs. This study also describes other potential targets and binding sites available for the SARS$\mathrm{CoV}-2$ infection. These markers can be considered as targets for drugs that could be designed for plausible therapeutics and prophylactics against COVID-19. The current treatment involves the use of ACE inhibitors (ACEi), $\mathrm{AT}_{1} \mathrm{R}$ blockers (ARBs), recombinant receptor-binding domain (RBD), mesenchymal stem cells (MSCs), cyclodextrin-soluble ACE2, and serine and cysteine protease inhibitors based therapies. Currently, few drugs are used for the treatment, and few vaccine sets are under trial. However, several receptors and proteins are summarized that require to be elucidated to find targets and domains. Previous studies show that the receptors and their prominent expression could help in the synthesis of novel compounds that could be potential drug candidates in treating coronavirus infection. The coronaviruses' (SARSCoV, SARS-CoV-2, and MERS-CoV) infection along with possible treatments is represented in Fig. 1.

\section{Similarity of SARS-CoV-2 with other coronaviruses}

The Coronaviridae family is categorized into four main subgroups: alpha, beta, gamma, and delta. The alpha and beta subgroups represent seven human coronaviruses, wherein five infectious human coronaviruses (OC43, HKU1, SARSCoV, SARS-CoV-2, and MERS-CoV) belong to betacoronaviruses, while the other two belong to alphacoronaviruses (229E and NL63) (Zhou et al. 2020a). Also, HKU4 and HKU5 are bat coronaviruses belonging to betacoronaviruses (Wang et al. 2014). Another bat SARS-like coronavirus, SLCoV-RaTG13 (Zhou et al. 2020a) (betacoronavirus (Malaiyan et al. 2020)) is a distinct clade from MERS-CoV (Petrosillo et al. 2020; Zhou et al. 2020a; Malaiyan et al. 2020). Nevertheless, the SARS-CoV-2 shares a close resemblance to SL-CoV-RaTG13 (sequence identity 96\%) compared to SARS-CoV (sequence identity 79\%) and MERS-CoV (sequence identity 50\%) (Kim et al. 2020; Lu et al. 2020; Zhou et al. 2020a). The MERS-CoV gene shows the highest sequence similarity to the bat coronavirus, HKU4, compared to HKU5 (Mann et al. 2008). Understanding the critical differences between the two closely related viruses, SARSCoV-2 and SL-CoV-RaTG13, would likely find the genetic mutations, alterations in the process of its evolution, and strategically designing target-specific drugs. The inhibitors that would target SL-CoV-RaTG13 may also work effectively on SARS-CoV-2.

\section{Structural similarity between SARS-CoV, SARS-CoV-2, and MERS-CoV with their key domains}

The Coronaviridae family has a positive-sense singlestranded RNA with diverse open reading frames (ORFs) that encode for different non-structural, structural, and accessory proteins, which are crucial for viral replication (Fehr and Perlman 2015). The coronaviruses contain several ORFs like 14 in SARS-CoV-2 (Wu et al. 2020), 12-13 in MERS-CoV, and 10 in SARS-CoV (Groneberg et al. 2005; Ramadan and Shaib 2019). The coronaviruses share few common structural proteins that are encoded at the $3^{\prime}$ end of the viral genome, which includes S-protein, an envelope protein $(\mathrm{E})$, membrane protein $(\mathrm{M})$, and nucleocapsid $(\mathrm{N})$ (Fehr and Perlman 2015) (Table 1). The 3' genome of SARS$\mathrm{CoV}-2$ also encodes for eight accessory proteins (Wu et al. 2020; Derington et al. 2020). At the 5' end of the genome of SARS-CoV-2, the ORF1 and ORF2 encode for sixteen non-structural proteins (nsps), which are crucial for viral replication (Wu et al. 2020; Derington et al. 2020). SARS$\mathrm{CoV}-2$ genome encodes approximately twenty-five proteins, including the S-protein, two proteases involves in cleaving human proteins, polymerases, and endoribonuclease act on RNA, which are responsible for viral infection and replication (Parks and Smith 2020).

The S-protein that associates and binds with cellular receptors for infection are a characteristic feature of the Coronaviridae family. Its nature influences the features related to transmissibility and pathogenesis (Liu et al. 2020b). The S-protein of MERS-CoV, SARS-CoV, and SARS-CoV-2 is a class 1 fusion protein consisting of two subunits (Bosch et al. 2003). The first $S 1$ receptor-binding unit forms the head that contains RBD (Wu et al. 2020; Bosch et al. 2003), whereas the S2 fusion subunit present in the stalk of spike protein of the coronaviruses (Fehr and Perlman 2015). The M-protein is present in large quantities in the virion that provides shape to the developing virus (Fehr and Perlman 2015; Armstrong et al. 1984). E-protein facilitate the virus's assembly and release, and is present in small quantities on the virion surface. Coronaviruses share a typical architecture of E-protein 


\section{SARS-COV-2}
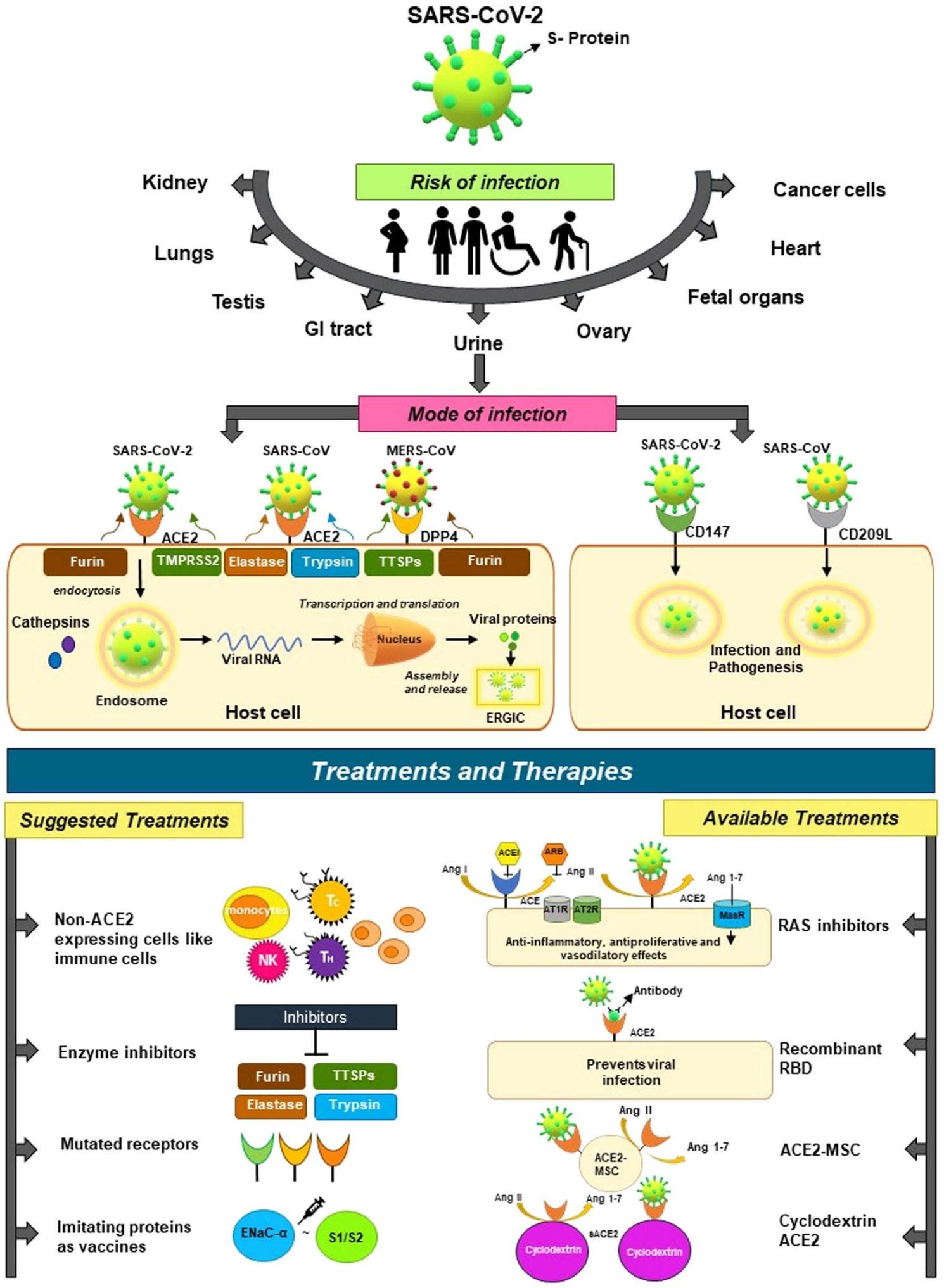

but with varied structures (Fehr and Perlman 2015; Godet et al. 1992). Also, the SARS-CoV has an ion channel activity, playing an essential role in pathogenesis (Nieto-Torres et al. 2014). The $N$ protein has $\mathrm{N}$ and $\mathrm{C}$ terminal domains, which play a vital role in the in vitro RNA binding through two different mechanisms (Fehr and Perlman 2015; Chang et al. 2006; Hurst et al. 2009). The information of structural proteins of coronavirus is listed in Table 1. 
4Fig. 1 Illustrates coronavirus infectivity with the target receptor of interaction and other host receptors involved in viral entry and infection. SARS-CoV and SARS-CoV-2 bind to ACE2, it would lead to Ang II's overaccumulation that causes pathophysiological effects in the host cell subsequently to the human system. After binding to the receptor, with the help of host cellular enzymes, the virus would internalize through the endosomal pathway and release the viral RNA that would bind to the host cell genome. This would lead to transcription and translation of viral proteins assembled in the endoplasmicreticulum-Golgi intermediate complex (ERGIC) and released as small viral particles through exocytosis. Other prominent receptors involved for coronavirus infection are CD147 and CD209L for both SARS$\mathrm{CoV}$ and SARS-CoV-2, while DPP4 is the receptor involved for MERS-CoV infection. Various therapies have been proposed to use RAS inhibitors like ACEi/ARB, recombinant RBD, ACE2-MSC, and cyclodextrin-soluble ACE2 to prevent and reduce the viral load and infection. Along with these possible therapies like the use of enzyme inhibitors, mutated target receptors, non-ACE2 expressing immune cells, and the use of proteins like ENAC $\alpha$ as a vaccine candidate that mimics the $\mathrm{S} 1 / \mathrm{S} 2$ subunit

Unlike SARS-CoV and SARS-CoV-2, the MERS-CoV entry inside human cells has been confirmed by a crystal structure of complex RBD of MERS-CoV and DPP4 (Petrosillo et al. 2020; Wang et al. 2013, 2014; Tai et al. 2020). Further, the MERS-CoV's RBD has two subdomains: a core that is highly similar to the RBD of SARS-CoV (Wang et al. 2013), and a receptor-binding subdomain, which associates with the DPP4 $\beta$-propeller. Although, structural superimposition showed a root mean square deviation (RMSD) of $3.8 \AA$ between S-protein of SARS-CoV-2 and SARS-CoV, both have a binding affinity for ACE2 (Chen et al. 2020; Kumar et al. 2020; Wrapp et al. 2020). The binding affinity of SARS-CoV-2 for ACE2 is 10-20 times higher than of SARS-CoV (Wrapp et al. 2020). Thus, SARS-CoV-2 is highly contagious and transmissible, though having a lower mortality rate (Petrosillo et al. 2020) than SARS-CoV and MERS-CoV, which are chiefly responsible for the nosocomial spread (Malik et al. 2020).

The docking studies of human ACE2 with SARS-CoV-2 S-protein identify the SARS-CoV-2 hotspot residues, Leu441, Phe472, Gln479, Ser480, Asn487, and Tyr491 (Chen et al. 2020), while the X-ray crystallographic threedimensional (3D) structure (PDB ID: 6M0J) showed interacting residues Lys417, Leu455, Phe486, Gln493, Gln498, Leu455, and Asn501 (Lan et al. 2020). The SARS-CoV2's S-protein RBD bind with ACE2 through the interacting residues, RBD: Leu455-ACE2: Asp30, Lys31, and His34; RBD: Lys417-ACE2: Asp30; RBD: Phe486-ACE2: Gln24, Leu79, Met82, and Tyr83; RBD: Gln493-ACE2: Lys31, His34, and Glu35; RBD: Gln498-ACE2: Asp38, Tyr41, Gln42, Leu45, and Lys353; RBD: Asn501-ACE2: Tyr41, Lys353, Gly354, and Asp355 (Lan et al. 2020). The complex 3D structure and interacting residues between the SARS-CoV-2 RBD domain and ACE2 are illustrated in Fig. 2.
Moreover, the mutations in the RBD of SARS-CoV were linked to pathogenic interactions with human ACE2. The SARS-CoV S-protein mutations, C348A, D454A, C467A, C474A, E452A, and D463A, abrogate their association with ACE2 (Wong et al. 2004). Although, mutations like R667S resulted in partial loss of cell-cell fusion and R797N lead to impairment to trypsin mediated membrane fusion (Follis et al. 2006; Belouzard et al. 2009). However, K672S mutation did not affect the cell-cell fusion mechanism (Follis et al. 2006), while C323A and D480A had no effect in binding with ACE2 (Wong et al. 2004). Similar cases of these mutations were also observed in SARS-CoV-2 (Wu et al. 2020; Wan et al. 2020). However, six mutations occur in other regions of RBD, the sub-domain region of the $\mathrm{S} 1$ subunit of SARS-CoV-2. The function of these mutations in viral pathogenicity must be further investigated (Petrosillo et al. 2020; Wu et al. 2020; Ge et al. 2013). Among the unsubstituted regions of SARS-CoV-2 concerning SARS-CoV and six mutated regions in the RBD of SARS-CoV-2, there is a possibility that these alterations could be a reason for the stronger affinity to the ACE2 receptor and hence, causing lower pathogenicity. Changes in these mutations may reduce their binding affinity or pathogenesis, which can be a therapeutic approach for a better vaccine alternative. However, there could be a risk of higher binding affinity and pathogenesis in subsequent mutations and, therefore, must be adequately investigated.

Furthermore, the S-protein of MERS-CoV (Kleine-Weber et al. 2018), and SARS-CoV-2 (Coutard et al. 2020), harbors a particular S1/S2 furin cleavage site, which is distinct from SARS-CoV, possessing peculiar infectious properties (Coutard et al. 2020; Xia et al. 2020). In SARS-CoV-2 insertion of four amino acids (residues of proline, two arginines, and alanine, underlined, SPRRAR $\downarrow S$, this indicating the motifs $(\mathbf{K} / \mathbf{R})-(X)_{n}-(\mathbf{K} / \mathbf{R}) \downarrow$, where $n=0,2,4$ or 6 and $X$ is any amino acid) was observed at the $\mathrm{S} 1 / \mathrm{S} 2$ site making it potential cleavage site for the furin protease and considered as a "polybasic" or "multibasic" site ( site cleaved by a wide variety of proteases to activate precursor proteins) (Coutard et al. 2020; Jaimes et al. 2020; Seidah and Chretien 1999).

The binding of MERS-CoV to DPP4, and SARS-CoV and SARS-CoV-2 to ACE2 triggered each of the three units of heptad repeat 1 (HR1) and HR2 domains of S2 subunit to interact with each other through hydrophobic forces, thus forming a six-helix bundle (6-HB) fusion core (Yuan et al. 2017). The fusion core brings the virus and cell plasma membranes close to each other for fusion and infection (Bosch et al. 2004). The X-ray crystallographic studies show that the 6-HB fusion core established by the assembly of HR1 and HR2 of SARS-CoV-2 shares similarities to MERSCoV 6-HB and SARS-CoV 6-HB with RMSD $0.36 \AA$ and $0.66 \AA$ respectively for all the $\mathrm{C} \alpha$ atoms proved that they have highly conserved regions (Zhou et al. 2020a; Xia et al. 
Table 1 Three-dimensional (3D) protein structural details of coronaviruses (SARS-CoV, SARS-CoV-2 and MERS-CoV) (Source: https://www. rcsb.org/)

\begin{tabular}{|c|c|c|c|c|c|}
\hline PDB entry & Method & Resolution $(\AA)$ & Chains & Sequence position & Sequence length \\
\hline \multicolumn{6}{|l|}{ SARS-CoV } \\
\hline \multicolumn{6}{|l|}{ S-Protein } \\
\hline $5 \times 58$ & EM & 3.20 & $\mathrm{~A} / \mathrm{B} / \mathrm{C}$ & $14-1193$ & 1179 \\
\hline 5XLR & EM & 3.80 & $\mathrm{~A} / \mathrm{B} / \mathrm{C}$ & $1-1196$ & 1195 \\
\hline $6 \mathrm{ACC}$ & EM & 3.60 & $\mathrm{~A} / \mathrm{B} / \mathrm{C}$ & $1-1196$ & 1195 \\
\hline 6CRV & EM & 3.20 & $\mathrm{~A} / \mathrm{B} / \mathrm{C}$ & $14-1190$ & 1176 \\
\hline \multicolumn{6}{|c|}{ M-Protein } \\
\hline $3 \mathrm{I} 6 \mathrm{G}$ & X-ray & 2.20 & $\mathrm{C} / \mathrm{F}$ & $88-96$ & 8 \\
\hline \multicolumn{6}{|l|}{ E-Protein } \\
\hline 2MM4 & NMR & & A & $8-65$ & 57 \\
\hline $5 \times 29$ & NMR & & $\mathrm{A} / \mathrm{B} / \mathrm{C} / \mathrm{D} / \mathrm{E}$ & $8-65$ & 57 \\
\hline \multicolumn{6}{|l|}{ N-Protein } \\
\hline $2 \mathrm{OFZ}$ & $\mathrm{X}$-ray & 1.17 & A & $49-174$ & 125 \\
\hline $2 \mathrm{OG} 3$ & X-ray & 1.85 & A & $49-174$ & 125 \\
\hline \multicolumn{6}{|c|}{ SARS-CoV-2 } \\
\hline \multicolumn{6}{|l|}{ S-Protein } \\
\hline $6 \mathrm{VSB}$ & $\mathrm{EM}$ & 3.46 & $\mathrm{~A} / \mathrm{B} / \mathrm{C}$ & $1-1208$ & 1207 \\
\hline $6 \mathrm{VXX}$ & EM & 2.80 & $\mathrm{~A} / \mathrm{B} / \mathrm{C}$ & $14-1211$ & 1197 \\
\hline 6VYB & EM & 3.20 & $\mathrm{~A} / \mathrm{B} / \mathrm{C}$ & $14-1211$ & 1197 \\
\hline \multicolumn{6}{|l|}{ N-Protein } \\
\hline 6VYO & X-ray & 1.70 & $\mathrm{~A} / \mathrm{B} / \mathrm{C} / \mathrm{D}$ & $47-173$ & 126 \\
\hline \multicolumn{6}{|c|}{ MERS-CoV } \\
\hline \multicolumn{6}{|l|}{ S-Protein } \\
\hline $4 \mathrm{~L} 72$ & X-ray & 3.00 & $\mathrm{~B}$ & $382-585$ & 203 \\
\hline 4NJL & X-ray & 2.30 & $\mathrm{~A}$ & 984-1063 & 79 \\
\hline
\end{tabular}

SARS-CoV severe acute respiratory syndrome coronavirus, $M E R S$ - $C o V$ Middle East Respiratory Syndrome coronavirus, $S$ spike, $M$ membrane, $E$ envelope, $N$ nucleocapsid, $P D B$ Protein Data Bank, $E M$ electron microscopy, $N M R$ nuclear magnetic resonance

2020). The shape of coronaviruses' 6-HB structure is rodlike, attained a length of $115 \AA$ and a diameter of $25 \AA$ (Xia et al. 2020). S2 subunit's 6-HB structure plays a vital role in the membrane fusion process and can be targeted to develop inhibitors against viral fusion and infection (Lan et al. 2020; Xia et al. 2020).

The similarity in the HR2 domain of SARS-CoV and SARS-CoV-2 could also serve as a common target for designing monoclonal antibodies and drugs by destabilizing the $6 \mathrm{HB}$ core structure to prevent virus cell entry and pathogenesis. A study indicated that the 47D11 mAb (monoclonal antibody) targeting S-protein trimer inhibits SARS-CoV-2, including SARS-CoV (Wang et al. 2020a).

Besides, the SARS-CoV and SARS-CoV-2 also have infectious proteases involved in transcription and replication, which are aided by the nsps, RNA dependent RNA polymerase (RdRp) (Masters 2006; Astuti 2020), and other subunits of the replicase-transcriptase complex (RTC) (Liu et al. 2020a; Ou et al. 2020), produced via cleavage of bulk replicase polyprotein $1 \mathrm{a}(\mathrm{pp} 1 \mathrm{a})$ and pplab by $3 \mathrm{C}$ like protease (3CL $\left.{ }^{\text {pro }}\right)$. The $3 \mathrm{CL}^{\text {pro }}\left(\mathrm{M}^{\mathrm{pro}}\right)$ (PDB_ID: 6LU7), the main protease in SARS-CoV-2, has a similar structure and sequence concerning SARS-CoV involved in viral replication and transcription (Jin et al. 2020a). The $\mathrm{M}^{\text {pro }}$ Cys 145 residue can serve as an attractive drug target in playing a vital role in inhibiting viral pathogenesis (Liu et al. 2020a; Jin et al. 2020a). The in silico computational studies identified compounds such as Itacitinib, Oberadiol, Telcagepant, Vidupiprant, Pilaralisib, Poziotinib, Fostamatinib, CL-275838, Ziprasidone, Leucal/Folinic Acid, and ITX506 (Liu et al. 2020a), inhibit both SARS-CoV and SARS-CoV-2 by targeting $\mathrm{M}^{\text {pro }}$ at Cys 145 . Hepatitis $\mathrm{C}$ virus protease inhibitors, Boceprevir and Telaprevir (Ma et al. 2020a), calpain inhibitors II and XII, GC-376 (Ma et al. 2020a), and $\alpha$-ketoamide inhibitors (Zhang et al. 2020a) effectively block the activity of $\mathrm{M}^{\text {pro }}$ to inhibit SARS-CoV-2. In contrast, some $\mathrm{M}^{\text {pro }}$ inhibitors were shown to be ineffective for SARS-CoV and SARS-CoV-2. However, Boceprevir displayed a broad-spectrum anti-viral activity by inhibiting SARS-CoV-2, SARS-CoV, MERS-CoV, HCoV-229E, 


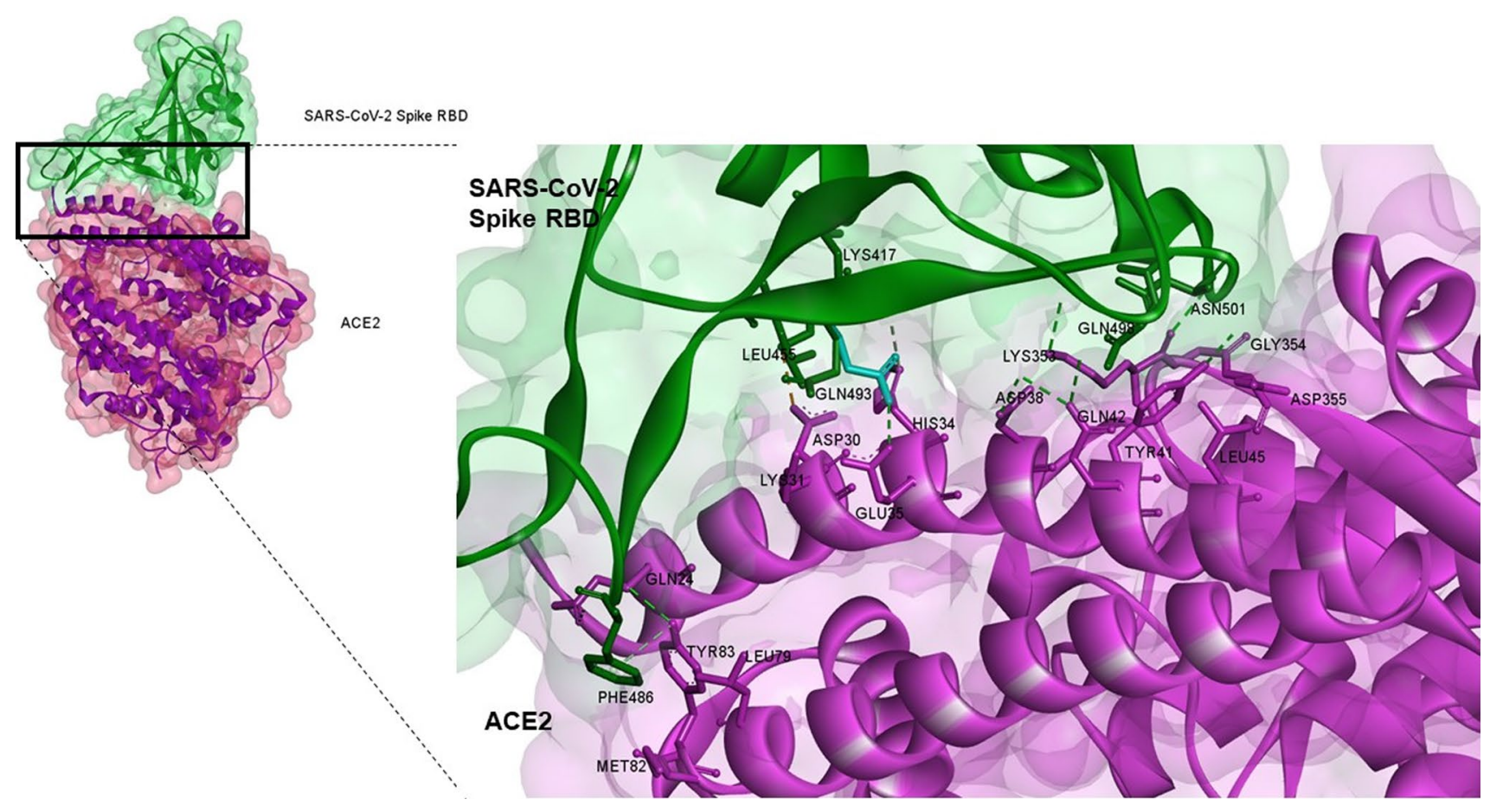

Fig. 2 3D complex structure of SARS-CoV-2 Spike RBD with human ACE2 and their interacting residues (PDB_ID: 6M0J)

HCoV-OC43, and HCoV-NL63 (Hu et al. 2020). The human rhinovirus protease inhibitor Rupintrivir (Hilgenfeld 2014) is effective against $\mathrm{HCoV}-229 \mathrm{E}$, but it could not inhibit the activity of $\mathrm{M}^{\text {pro }}$ in SARS-CoV and SARS-CoV-2 (Ma et al. 2020a; Kim et al. 2012). The in silico studies indicated that HIV-1 protease inhibitors Lopinavir and Ritonavir (Nutho et al. 2020) is a novel $\mathrm{M}^{\text {pro }}$ inhibitors. However, in vitro and in vivo studies showed that these inhibitors could not reach the effective pharmacokinetic concentration for inhibiting $\mathrm{M}^{\text {pro }}$ (Zhang et al. 2020b).

An in-depth structural analysis of $\mathrm{M}^{\text {pro }}$ would be likely to identify or design an anti-viral compound. There are three nsps of SARS-related viruses, namely nsp1, nsp2, and nsp3, processed by papain-like protease $\left(\mathrm{PL}^{\mathrm{pro}}\right)$ found in the SARS virus that cleaves the $\mathrm{N}$ terminal of these nsps (Hilgenfeld 2014). A lead compound GRL0617 and its modified form suppress the activity of PL ${ }^{\text {pro }}$ (Hilgenfeld 2014). It could also be used to find the overall function of $\mathrm{PL}^{\text {pro }}$, which further needs to be investigated. Hence, understanding the viral infection identifies the potential targets involved that could be inhibited or neutralized accordingly.

\section{Mode of infection}

SARS-CoV-2 infection is triggered through the binding of its S1 subunit of S-protein with ACE2 (Walls et al. 2020). Afterward, SARS-CoV-2 entry also relays upon priming by the serine proteases, transmembrane protease serine subfamily 2 (TMPRSS2) (Li et al. 2003; Matsuyama et al. 2010). Also, the S2 subunits of SARS-CoV-2, responsible for membrane fusion, share $89.8 \%$ sequence identity to SARS-CoV (Zhou et al. 2020a). As the SARS-CoV-2 comes in close proximity to the host cell, the RBD of the S1 subunit of S-protein binds to the ACE2 of the target cells (Xia et al. 2020). Subsequently, the 6-HB fusion core is formed, in which the three units of both HR1 core and HR2 domain intertwine antiparallelly with each other in a coiled-coil manner, thus facilitating the fusion of virus and cell plasma membranes and causing infection (Bosch et al. 2004). However, clathrin and non-clathrin mediated endocytosis are an alternate route for internalization and coronaviruses' entry in the absence of membrane-bound or exogenous proteases (Inoue et al. 2007; Wang et al. 2008). After the viral entry into the cells, SARS-CoV-2 and SARS-CoV RNA replication and transcription are aided by the nsps like RdRp and helicase produced through cleavage of pp1a and pplab by their respective proteases $\mathrm{M}^{\text {pro }}$ (Jin et al. 2020a) (3CL ${ }^{\text {pro }}$ (Zumla et al. 2016)), while the $\mathrm{N}$ terminal of the nsps is cleaved by the PL ${ }^{\text {pro }}$ (Hilgenfeld 2014). The RTC formation by the nsps occurs in the double-membrane vesicles, the RdRp and helicase containing subunits. Subsequently, the transcription of an endogenous genome template mediated by the RTC occurs in the sub-genomic RNA's negative-sense genes and the progeny genome, which then transcribes the positive-sense mRNAs. The transcribed sub-genomic RNA further translates into structural and accessory proteins: 


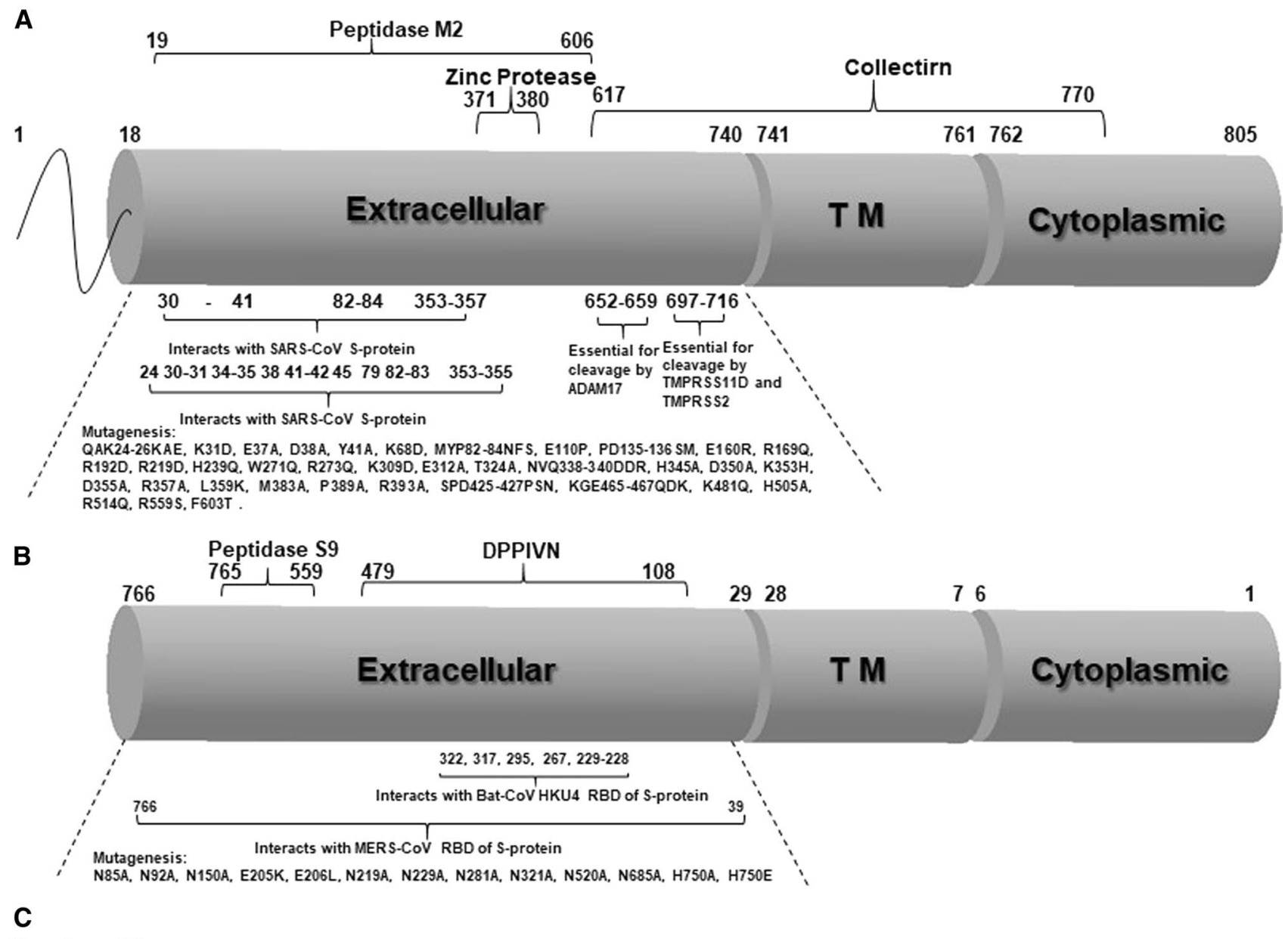

Signal peptide

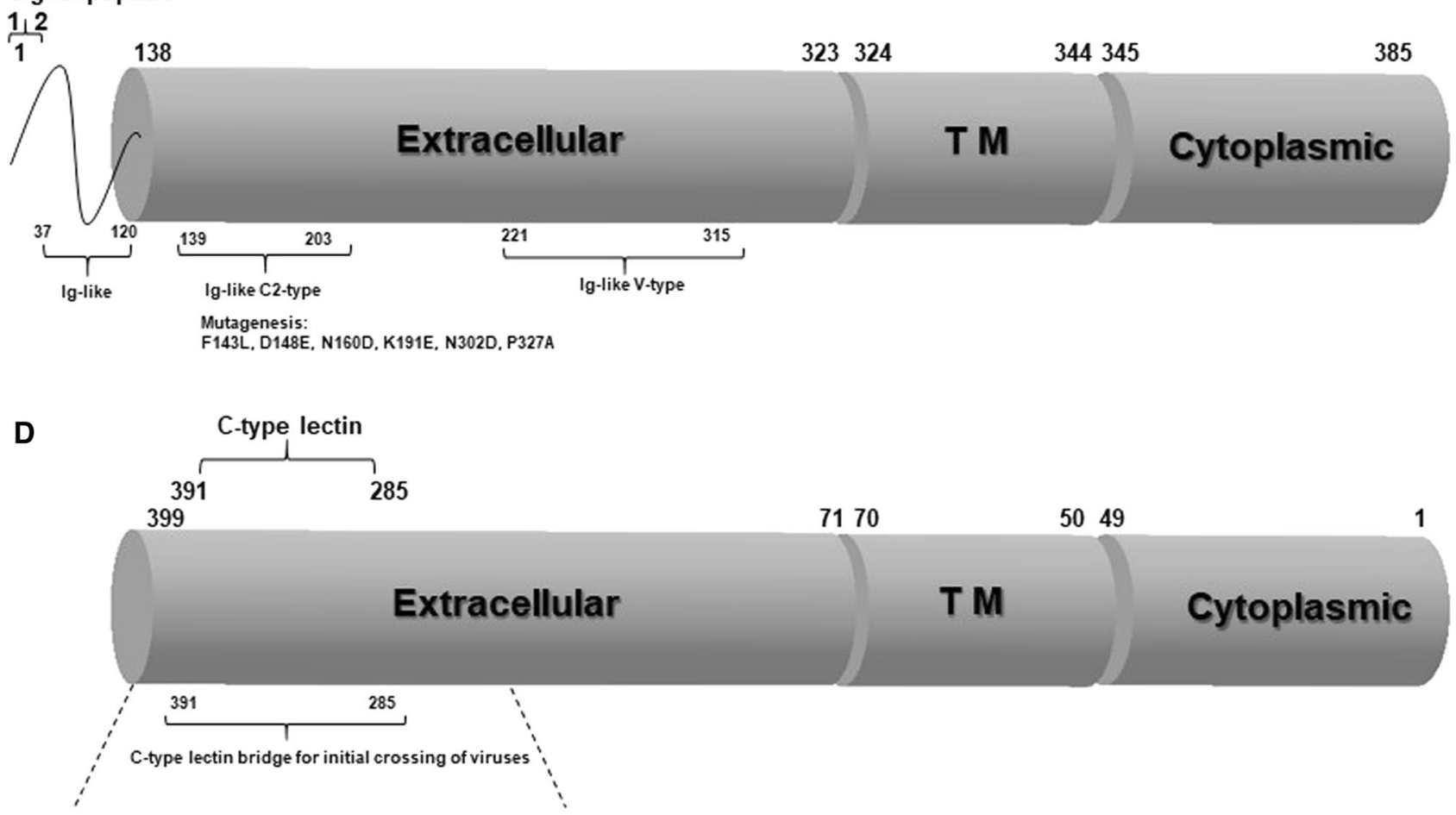


4Fig. 3 The line Diagram of prominent receptors for coronavirus infection. These receptors represent the main topological domains: extracellular, transmembrane (TM), and cytoplasmic along with mutagenesis and interacting regions with viruses: a ACE2 (Uniprot ID: Q9BYF1) (Lan et al. 2020), b DPP4 (Uniprot ID: P24487) (Wang et al. 2013, 2014). c CD147 (Uniprot ID: P35613), d CD209L (Uniprot ID: Q9H2X3). The protein mutagenesis data has also been mentioned along with major protein domains

$\mathrm{S}, \mathrm{M}$, and $\mathrm{E}$ and are packed into the endoplasmic reticulum and then moved to the endoplasmic reticulum-Golgi intermediate compartment (ERGIC). The $\mathrm{N}$ protein is then transcribed and joins the prior replicated genome program forming nucleocapsid before moving into ERGIC. Within the ERGIC, assembly of nucleocapsid with other structural proteins results in small virion coated vesicles released out of the cell through exocytosis (Astuti 2020). Moreover, MERS-CoV interacts with receptor DPP4 for their entry into the host's cells (Wang et al. 2014; Tai et al. 2020; Raj et al. 2013). However, the complete pathway of infection further needs to be investigated to understand its potential domain that causes infection.

\section{Human cellular receptors as targets of coronaviruses}

Prominent binding receptors like DPP4 for MERS-CoV, ACE2 for SARS-CoV and SARS-CoV-2 (Xu et al. 2020; Kim et al. 2020; Zhou et al. 2020a), other receptors such as CD147 and CD209L are also identified to be involved in SARS-CoV-2 infection (Wang et al. 2020; Amraie et al. 2020). Furthermore, human proteins and enzymes involved during the viral entry could serve to be potent targets for coronavirus.

\section{DPP4 or CD26: a binding receptor for MERS-CoV}

DPP4 or CD26 is a type-II transmembrane protein that helps in regulating different physiological processes (Gorrell et al. 2001). The complex structure analysis indicates that bat coronavirus, HKU4 RBD is associated with human CD26 (hCD26) for entry into the cell (Wang et al. 2014; Lau et al. 2013). The complex structure of HKU4 RBD and hCD26 (PDB_ID: 4QZV) revealed that RBD of MERS-CoV and HKU4 have a higher identity (54.4\%) and also share a similar binding mode to hCD26 (Wang et al. 2014; Tai et al. 2020; Raj et al. 2013). The receptor-binding subdomain in the RBD of MERS-CoV has key residues critical for binding with DPP4 (Wang et al. 2013). Although a recent study on HKU4 suggests that MERS-CoV would have originated from bats (Wang et al. 2014). The expression of DPP4 is high in alveolar type 1 (AT1) and alveolar type 2 (AT2) cells of lung alveoli, endothelial cells, non-ciliated bronchial epithelial cells of the liver, intestine, kidneys, thymus, and hemopoietic cells (HSCs) of bone marrow (Memish et al. 2020). These cells with high DPP4 expression would correspond to MERS-CoV spreading extensively across the body.

\section{CD147 an alternative target of SARS-CoV-2}

CD147 receptor is also known as Basigin or Extracellular Matrix Metalloproteinase Inducer (EMMPRIN), a highly glycosylated transmembrane protein of immunoglobulin superfamily that acts as a leading upstream simulator of matrix metalloproteases (MMPs). The MMPs are highly expressed in asthma, diabetes, influenza, and cancer. The cancer cells have a high expression of CD147 (Mattos et al. 2002; Moheimani et al. 2018; Bao et al. 2010), which is associated with inflammatory responses. In malaria patients, CD147 serves as a receptor for cell entry of Plasmodium falciparum (Crosnier et al. 2011). Studies reported that CD147 also serves as a new route for SARS-CoV-2 infection (Wang et al. 2020). The virus invaded the host cell by S-protein binding to CD147 (Wang et al. 2020). Abundant CD147 expression is observed in macrophages and AT2 cells in pulmonary fibrosis (Guillot et al. 2006), leading to acute effects of COVID-19. This de novo route of entry is plausibly because of adaptation, and both the pathogens (Plasmodium and SARS-CoV-2) likely share a common domain for their entry into the cells via CD147, which needs to be further studied. Also, blocking CD147 would be able to reduce pulmonary fibrosis due to SARS-CoV-2 infection.

\section{CD209L a SARS-CoV and SARS-CoV-2 target}

CD209L or dendritic cell-specific intercellular adhesion molecule (ICAM) 3-grabbing nonintegrin (DC-SIGN) is an HIV-1 receptor. CD209L is expressed on dendritic cells commonly, but its expression level is higher in lymphatic endothelial cells than that of ACE2 (Li et al. 2007). Despite of having lower affinity, it serves as a substitute receptor in SARS-CoV infection (Magrone et al. 2020), and facilitates entry passage for other RNA viruses like Sindbis and Ebola. While Hepatitis C virus (HCV) and Human Immunodeficiency Virus (HIV) may bind to CD209L, it does not necessarily guide their entry into the host cells. Immunohistochemical (IHC) studies show that along with ACE2, CD209L is also expressed in AT2 and endothelial cells of the human respiratory system. Studies suggest that other than ACE2, the S-protein of SARS-CoV can also use CD209L for viral infectivity and pathogenesis (Jeffers et al. 2004). The C-type lectin present in CD209L (UniProt ID: Q9H2X3) (Fig. 3) acts as an entry portal for various pathogens. Mutagenesis studies occur in this region will help in preventing the entry of these pathogens. Like SARS-CoV, a recent study also revealed that CD209L could also serve as 
receptors for SARS-CoV-2 infection (Amraie et al. 2020). The line diagram of receptors ACE2, DPP4, CD147, and CD209L, along with interacting regions is represented in Fig. 3.

\section{ACE2 a target of SARS-CoV and SARS-CoV-2}

ACE homologous zinc metalloprotease carboxypeptidase enzyme, ACE2, is composed of 805 amino acids (Fig. 3). The full-length form of ACE2 is a type 1 transmembrane glycoprotein that consists of a single extracellular catalytic domain ( $\mathrm{N}$ terminal), a small transmembrane segment, and a short intracellular cytoplasmic tail (C terminal) (Patel et al. 2014).

The membrane-anchored protein enzyme, A Disintegrin and Metalloproteases 17 (ADAM17) cleaves ACE2 and converts it into a shorter and soluble form, with the ability of circulating in the blood at low levels. Ang II type 1 receptor $\left(\mathrm{AT}_{1} \mathrm{R}\right)$ upregulates the expression of ADAM17 and increases soluble ACE2 (sACE2) levels (Serfozo et al. 2020; Arendse et al. 2019; Xu et al. 2017). Accumulation of Ang II through $\mathrm{AT}_{1} \mathrm{R}$ produces pro-inflammatory effects that may lead to acute lung injury or myocarditis (Zhonghua et al. 2020). Nonetheless, membrane-bound ACE2 inhibits Ang II activity in the Renin-Angiotensin System (RAS) by degrading Ang II into Ang 1-7, which elicits anti-inflammatory effects through Angiotensin type 2 receptor $\left(\mathrm{AT}_{2} \mathrm{R}\right)$ and Mas receptor pathway (Fig. 4). Also, ACE2 cleaves Ang I to release Ang 1-9 during the suppression of ACE2, although ACE2 has 400 folds higher affinity and higher catalytic efficiency for Ang II than Ang I (Arendse et al. 2019; Cheng
Table 2 3D structural details of human cell receptors that bind with coronaviruses (SARS-CoV, SARS-CoV-2, and MERS-CoV) (Source: https://www.rcsb.org/)

\begin{tabular}{|c|c|c|c|c|c|}
\hline PDB entry & Method & $\begin{array}{l}\text { Resolution } \\
(\AA)\end{array}$ & Chains & $\begin{array}{l}\text { Sequence } \\
\text { position }\end{array}$ & $\begin{array}{l}\text { Sequence } \\
\text { length }\end{array}$ \\
\hline \multicolumn{6}{|l|}{ ACE2 } \\
\hline $1 \mathrm{R} 42$ & X-ray & 2.20 & A & $1-615$ & 614 \\
\hline $1 \mathrm{R} 4 \mathrm{~L}$ & X-ray & 3.00 & A & $1-615$ & 614 \\
\hline $6 \mathrm{M} 0 \mathrm{~J}$ & X-ray & 2.45 & A & 19-615 & 596 \\
\hline $6 \mathrm{M} 17$ & EM & 2.90 & $\mathrm{~B} / \mathrm{D}$ & $18-805$ & 787 \\
\hline \multicolumn{6}{|l|}{ DPP4 } \\
\hline $1 \mathrm{~J} 2 \mathrm{E}$ & X-ray & 2.60 & $\mathrm{~A} / \mathrm{B}$ & $33-766$ & 733 \\
\hline 1PFQ & X-ray & 1.90 & $\mathrm{~A} / \mathrm{B}$ & $36-766$ & 730 \\
\hline $4 \mathrm{~A} 5 \mathrm{~S}$ & X-ray & 1.62 & $\mathrm{~A} / \mathrm{B}$ & $39-766$ & 727 \\
\hline $4 \mathrm{~N} 8 \mathrm{D}$ & X-ray & 1.65 & $\mathrm{~A} / \mathrm{B}$ & 39-766 & 727 \\
\hline \multicolumn{6}{|l|}{ CD147 } \\
\hline $3 I 84$ & X-ray & 2.00 & $\mathrm{~A} / \mathrm{B}$ & 13-219 & 206 \\
\hline 4U0Q & X-ray & 3.10 & $\mathrm{~B} / \mathrm{D}$ & $1-385$ & 384 \\
\hline \multicolumn{6}{|l|}{ CD209L } \\
\hline 1SL6 & X-ray & 2.25 & $\begin{array}{c}\mathrm{A} / \mathrm{B} / \mathrm{C} / \mathrm{D} / \\
\mathrm{E} / \mathrm{F}\end{array}$ & 216-399 & 183 \\
\hline 1XAR & X-ray & 2.25 & $\mathrm{~A} / \mathrm{B}$ & 216-399 & 183 \\
\hline $1 \mathrm{XPH}$ & X-ray & 1.41 & $\mathrm{~A}$ & $250-399$ & 149 \\
\hline
\end{tabular}

$A C E 2$ angiotensin-converting enzyme 2, DPP4 dipeptidyl peptidase 4, $P D B$ Protein Data Bank, EM electron microscopy

et al. 2020; Vickers et al. 2002). The structural information of binding receptors is listed in Table 2.

The overall function of ACE2 in the entry of SARS-CoV and SARS-CoV-2 is to act as a counter-regulatory force for

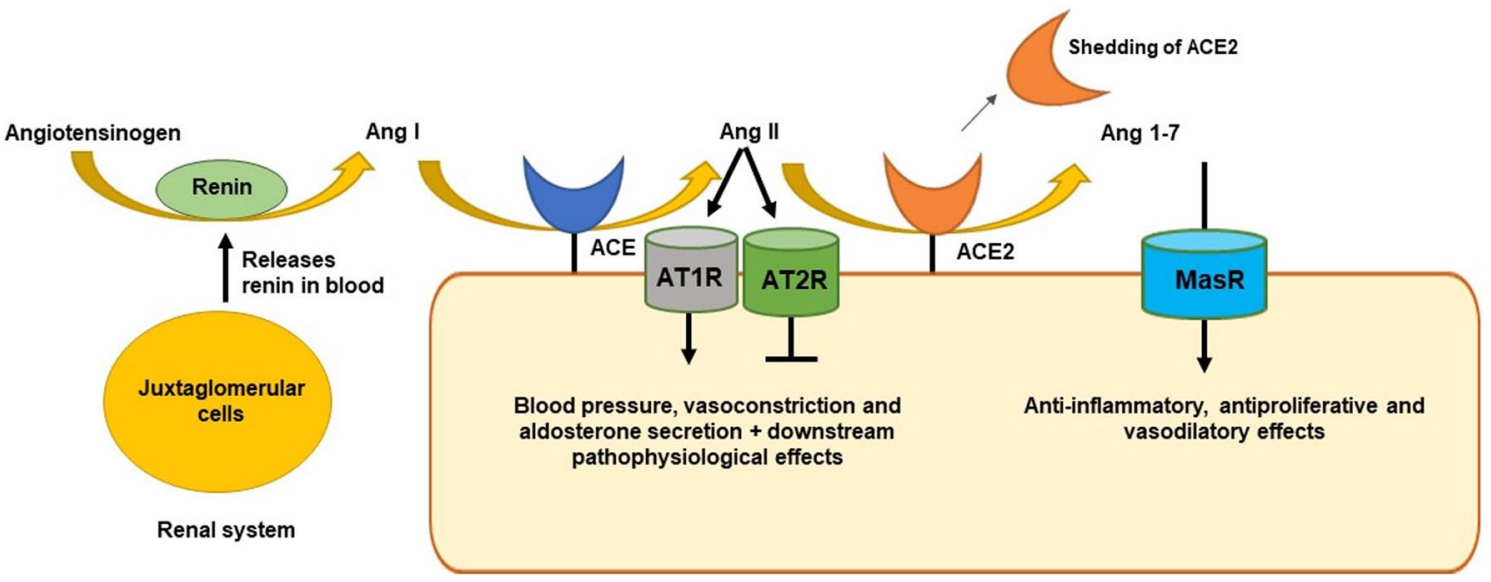

Fig. 4 The physiological role of ACE and ACE2 in the RAS pathway. During hypotension, the juxtaglomerular cells of the renal system releases renin into the blood that circulates into the body. Renin subsequently breaks down Angiotensinogen to Ang I. The Ang I, with the help of ACE is further converted to Ang II, which leads to elevated blood pressure, vasoconstriction, aldosterone secretion and downstream pathophysiological effects through AT1R pathway.
Alternatively, these effects would be inhibited if Ang II mediates its effects through AT2R pathway (resulting in vasodilatory effect). The Ang II is further broken down to Ang 1-7 by ACE2 that elicits antagonistic effect to Ang II as Ang 1-7 that binds with Mas receptor (MasR) resulting in anti-inflammatory, antiproliferative, and vasodilatory effects. ADAM17 is known to be responsible for shedding membrane anchored proteins, thus releasing soluble ACE2 
RAS. It balances multiple ACE functions by targeting Ang II, protects the organs especially the cardiovascular system, and plays a crucial role in binding and absorption of amino acids in the renal system and GI tract by regulating the expression of Sodium-dependent neutral amino acid transporter ( $\mathrm{B}^{0} \mathrm{AT} 1$ ) (Sun et al. 2020; Clotet-Freixas et al. 2018; Ortiz-Melo and Gurley 2016; Vuille-Dit-Bille et al. 2015).

Conclusively, the mutagenesis studies revealed the favorable mutations in DPP4, ACE2, and CD147 that would likely have active interacting or dissociating sites for MERSCoV, SARS-CoV, and SARS-CoV-2 (Fig. 3). The COVID19 patients with comorbid conditions like cancer have an additional possibility of the mutations in the ACE2 receptor, which would make the patient susceptible or resistant to the SARS-CoV-2 infections. Such cases must be further investigated to understand the probable reasons of the virus binding to the mutated receptor. Similarly, in the course of evolution, mutations in receptors including DPP4 and CD147 could also either promote or prevent the binding affinity with the coronaviruses. Alternatively, there may also be a few mutations that would not affect the binding affinity. Hence, an understanding of these receptors and viral domains' mutation rate is required to delineate the mutations that would prevent viral entry and pathogenesis.

\section{Miscellaneous targets}

In the coronavirus pathophysiology, the enzymes such as serine cystine proteases, trypsin, furin, thermolysin, and elastase are required for viral entry (Xia et al. 2020; Belouzard et al. 2010; Tang et al. 2020). Meanwhile for endocytosis pathway, enzymes such as cathepsins, phosphatidylinositol 3-phosphate 5-kinase and two-pore segment channel are known to play key role during the coronavirus infection $(\mathrm{Ou}$ et al. 2020; Hoffmann et al. 2020).

\section{Transmembrane serine proteases are the target for SARS-CoV, SARS-CoV-2 and MERS-CoV}

The membrane-bound proteases family member, type-II transmembrane serine proteases (TTSPs) are involved in the influenza virus' infectivity. The influenza virus' activation and transmissibility are mainly through transmembrane protease serine subfamily 2 (TMPRSS2) and subfamily 4 (TMPRSS4) (Tang et al. 2020; Choi et al. 2009; Bertram et al. 2010; Böttcher et al. 2006; Chaipan et al. 2009). TMPRSS2 is a membrane-bound serine protease that takes part in proteolytic cascades to maintain the homeostasis of the prostate (Lucas et al. 2014).

Studies have shown that membrane-bound TMPRSS2 activates MERS-CoV, SARS-CoV, and their pseudo-particles (pp) like SARSpp and MERSpp for infection (SARSpp includes lentiviral particles incorporated with S-protein of
SARS-CoV (Simmons et al. 2004), replication defective Vesicular stomatitis virus (VSV) particles having S-protein of SARS-CoV-2 (Hoffmann et al. 2020), and MERSpp includes MERS-CoV S-protein expressing murine leukemia virus (MLV) vector (Zmora et al. 2018)). TMPRSS2 cleaves MERS-CoV, SARS-CoV, and SARS-CoV-2 at the S2 site to activate plasma membrane fusion (Tang et al. 2020; Hoffmann et al. 2020; Gierer et al. 2013; Qian et al. 2013; Shirato et al. 2013; Matsuyama et al. 2020), and facilitates cell entry of the SARS-CoV-2 after the binding of S-protein to the ACE2 (Danser et al. 2020). Likewise, TMPRSS4 activates cell-mediated fusion of MERS-CoV and SARS-CoV, but it does not activate infection. Other TTSPs, TMPRSS11a, and TMPRSS11e, activate S-protein fusion of MERS-CoV, while TMPRSS11a activates SARSCoV fusion S-protein, which causes infection (Tang et al. 2020; Kam et al. 2009). Human airway trypsin-like protease (HAT) known as TMPRSS11d, can activate MERS-CoV (Tang et al. 2020; Kam et al. 2009; Bertram et al. 2011). Although, transient expression of TMPRSS2, TMPRSS4, TMPRSS11a, TMPRSS11d, and TMPRSS11e enhances SARS-CoV-2 S-protein-mediated cell-cell fusion, these proteases activating the $S$-protein for infection are yet to be investigated (Ou et al. 2020; Tang et al. 2020).

\section{Furin-like proteases that cleave S1/S2 sites of MERS-CoV and SARS-CoV-2}

Furin is known to activate the fusion machinery of viral glycoproteins (Jaimes et al. 2020). Furin cleavage sites are available for the influenza virus, making it highly pathogenic (Kawaoka and Webster 1988). Similarly, SARS-CoV-2 and MERS-CoV also contain S1/S2 site cleaved by the furin or furin-like proteases present on the trans-Golgi network that attack the newly synthesized S-protein cleavage sites of these coronaviruses (Xia et al. 2020; Tang et al. 2020). The TMPRSS2 cleaves S2's position to establish plasma membrane fusion. However, other than the S1/S2 sites of SARSCoV-2 and MERS-CoV, the furin activity was not observed in the S2 site of SARS-CoV and SARS-CoV-2 that needs to be analyzed further (Walls et al. 2020; Kleine-Weber et al. 2018; Coutard et al. 2020; Mille and Whittaker 2014).

\section{Trypsin plays a role in activating membrane fusion during infection}

Trypsin is an exogenous protease acting as an activator for the fusion of the plasma membrane (Belouzard et al. 2009). This serine endopeptidase expression is commonly present in respiratory and digestive cells, especially in the small intestine where the enzyme is highly active (Jaimes et al. 2020). It consists of various cleavage conditions, unlike TMPRSS2 that functions even in the absence of the $\mathrm{S} 1 / \mathrm{S} 2$ cleavage site. 
Trypsin shows components of a two-step activation process in the SARS virus, such as cleaving arginine in the S1/S2 site and providing the $\mathrm{S} 2$ site for fusion (Belouzard et al. 2009). In a study, it has been indicated that trypsin induces protein-mediated cell-cell fusion in Vero E6 cells infected with SARS-CoV. Similarly, trypsin also induced MERS$\mathrm{CoV}$ and SARS-CoV-2 S-protein-mediated cell-cell fusion in Vero E6 and 293 T cells, respectively. Also, the increased undergo treatment with trypsin have been observed after the binding of retroviral pseudo-particles like SARSpp and MERSpp to ACE2 and DPP4, respectively. This resulted in enhancement in their effectiveness of infection at the plasma membrane surface indicating that trypsin is involved in the coronavirus infection (Tang et al. 2020). Alternatively, it has been hypothesized that trypsin pre-treatment prior to receptor binding would cause irreversible conformational change in S-protein and thus prevent infection. However, this phenomenon is yet to be investigated for SARS-CoV-2 (Tang et al. 2020).

\section{Elastase cleaves the S2 site of the S-protein in SARS-CoV}

The S2 cleavage of SARS-CoV is mediated by elastase near the trypsin cleavage site, implying that more than one cleavage site is present on the S-protein on the SARS virus (Belouzard et al. 2010). The S-protein induces flexibility in cleavage location, and mutagenic studies prove that elastase cleave at the trypsin cleavage site and enhance the virus's fusion ability. However, similarity and uniqueness of S1/S2 and $\mathrm{S} 2$ cleavage sites in both SARS-CoV-2 and MERS-CoV are yet to be identified (Tang et al. 2020).

\section{Role of thermolysin in entry and replication of SARS-CoV and MERS-CoV}

Thermolysin acts as an exogenous enzyme known to activate unidentified sites of SARS-CoV and MERS-CoV (Tang et al. 2020; Shirato et al. 2013; Matsuyama et al. 2005). The treatment with a high concentration of thermolysin and trypsin enhances the MERS-CoV entry and replication in VeroE6 cells, indicating that thermolysin may also play a role in infection (Matsuyama et al. 2005).

\section{Role of cathepsins in the endosomal pathway of SARS-CoV, SARS-CoV-2, and MERS-CoV}

Cathepsins are a group of cysteine proteases commonly found in lysosomes and endosomes (Regan et al. 2008) which take part in several degradative and antigen-presenting processes (Jaimes et al. 2020). They are activated in acidic $\mathrm{pH}$, wherein cathepsin $\mathrm{B}$ and $\mathrm{L}$ are the Coronaviridae family activators in Early and Late endosomes, respectively (Regan et al. 2008; Qiu et al. 2006). A cathepsin B/L inhibitor, MDL28170, inhibits the entry of MERS-CoV and SARSpp into MRC-5 cells (Gierer et al. 2013; Simmons et al. 2005; Huang et al. 2006). These inhibitors were also effective against SARS-CoV-2 (Ou et al. 2020; Hoffmann et al. 2020). However, more recent studies indicated that cathepsin L specific inhibitor, SID 26681509, prevented the SARS-CoV-2 entry into human embryonic kidney 293/hACE2 cells. However, cathepsin B specific inhibitor, CA-074, did not affect the viral entry into the cells (Ou et al. 2020; Pišlar et al. 2020). This indicated that cathepsin $L$ has a more important role in the SARS-CoV-2 expression (Pišlar et al. 2020; Gomes et al. 2020). Moreover, the expression of cathepsin $\mathrm{L}$ is associated with the extracellular matrix's degradation and was found significantly higher during chronic inflammation, a key attribute of SARS-CoV-2 infection (Gomes et al. 2020). The X-ray crystallographic studies indicated that the calpain inhibitors II and XII, GC-376 analogs: UAWJ246, UAWJ247, and UAWJ248, showed dual inhibition properties by inhibiting both $\mathrm{M}^{\text {pro }}$ and cathepsin L (Sacco et al. 2020). The early and late cathepsin inhibitors confirmed that these viruses get activated for fusion in late endosome (Ou et al. 2020; Simmons et al. 2005). However, the indirect dependencies of the SARS-CoV, SARS-CoV-2, and MERS-CoV on low-acidic $\mathrm{pH}$ activates the cathepsin $\mathrm{L}$ in the endosomal pathway, which acts on the S-protein followed by virus undergoing the next steps of fusion (Tang et al. 2020). Conversely, HCoV-NL63 is unable to utilize cathepsin L protease in the infection of ACE2 expressing host cells (Huang et al. 2006). Currently, the in silico and in vivo analysis of TMPRSS2 and cathepsin inhibitors have been studied, the in vivo anti-viral efficacy is yet to be confirmed.

\section{Phosphatidylinositol 3-phosphate 5-kinase and two-pore segment channel are essential for SARS-COV-2 entry}

Since endocytosis is an alternative mode of infection of the virus into the cells, phosphatidylinositol 3-phosphate 5-kinase (PIKFYVE) is required during SARS-CoV-2 infection through the endocytic pathway (Ou et al. 2020). This initiates phosphoinositides synthesis to regulate the formation of early endosome. Besides, a calcium channel, a two-pore segment channel (TPC2) activated by phosphoinositides in membranes of the lysosome is essentially required for endocytosis (Ou et al. 2020).

\section{Epithelium sodium channel C (ENaC)-a mimicking S1/S2 subunit}

Other than furin present on human cells for cleavage of S1/S2 sites, a similar peptide for the furin cleavage site on the $\mathrm{ENaC}-\alpha$ subunit is present (Anand et al. 2020). ENaC 
absorbs sodium ions in the airway surface liquid (ASL) along with transmembrane member 16 A (TMEM16A) and cystic fibrosis transmembrane conductance regulator (CFTR) that secretes chloride ions, thereby maintaining the hydration of the mucus layers (Gaillard et al. 2010). Hence among its subunits $\alpha, \beta$ and $\gamma$ (Gaillard et al. 2010), $\mathrm{ENaC}-\alpha$ plays a vital role in the homeostasis of ASL (Rossier and Stutts 2009) that generates inward sodium ion current (Canessa et al. 1994; Tarjus et al. 2017). The specific genetic mutations of $\mathrm{ENaC}-\alpha$ lead to a regulation imbalance of aldosterone in patients, impeding that the furin site is crucial for activating ENaC and $\mathrm{S} 1 / \mathrm{S} 2$ cleavage site SARSCoV-2 has targeted mimicry of ENaC- $\alpha$ (Rossier and Stutts 2009). The single-cell RNA sequencing (scRNA-Seq) data of 65 samples shows a prominent overlapping expression of $\mathrm{ACE} 2$ and $\mathrm{ENaC}-\alpha$ in cell types linked to the cardiovascularrenal-pulmonary physiopathology of SARS-CoV-2 infection (Anand et al. 2020). The potent receptors, enzymes, and active proteins involved during SARS-CoV-2, SARS-CoV, and MERS-CoV infection are summarized in Table 3.

Certain inhibitors block the virus entry by suppressing the interacting enzymes like TTSPs, trypsin, elastase, and thermolysin. The serine protease inhibitors like Camostat were partially able to block SARS-CoV infection and $\mathrm{HCoV}$ NL63 in HeLa cell lines. However, its synergistic effect with cathepsin inhibitor trans-epoxysuccinyl-L-leucylamindo3methylbutane ethyl ester (EST) in human Calu-3 airway epithelial cells efficiently prevents SARS-CoV entry inside host (Parks and Smith 2020; Memish et al. 2020; Kawase et al. 2012). The use of Camostat also prevented MERS-CoV entry in human Calu-3 bronchial submucosal gland cells by $10 \times$, and the viral growth reduced by $270 \times$. In contrast, co-treatment with EST, Leupeptin, or other serine, cysteine, and threonine peptidase inhibitors was not effective in preventing MERS-CoV infection (Shirato et al. 2013). Hence, these inhibitors could be used as a possible treatment in preventing the entry of SARS-CoV-2 growth and infection. Interfering the endosomal route of viral entry could also be accomplished by blocking the activities of cathepsins, PIKFYVE and TPC2, essential for the SARS-CoV-2 entry, to prevent further infection to organs. Further understanding of $\mathrm{ENaC}-\alpha$ for its resemblance to that of the $\mathrm{S} 1 / \mathrm{S} 2$ site could be a significant breakthrough in developing a recombinant protein that could design a suitable vaccine candidate.

\section{Role of ACE2 in the RAS pathway}

The RAS is an essential system required for regulating homeostasis in the body by playing a pivotal role in monitoring and controlling extracellular fluid volume and atrial vasoconstriction (Arendse et al. 2019; Cheng et al. 2020). During hypotension (reduced renal blood circulation and 
blood sodium levels), renin (a protease enzyme that cleaves Angiotensinogen) from the renal system's juxtaglomerular cells is released into the blood circulation (Arendse et al. 2019). It hydrolyzes serum globulin and converts Angiotensinogen to Ang I, Ang I into a vasoactive peptide Ang II in the presence of a zinc metalloprotease ACE. Ang II, facilitated by $\mathrm{AT}_{1} \mathrm{R}$ highly expressed in the cardiovascular system, increases blood pressure through vasoconstriction, aldosterone secretion, and sympathetic nervous system tension, ultimately eliciting downstream pathophysiological effects in classical RAS (Fig. 4) (Hanff et al. 2020; Arendse et al. 2019; Li et al. 2017; Tikellis et al. 2011). It also promotes the inflammatory response of cells, fibrosis, and myocardial hypertrophy. In the counter-regulatory RAS pathway, ACE2 plays an antagonistic role by cleaving Ang II and releasing Ang 1-7 that binds with G-protein Coupled Receptor (GPCR) and Mas receptor. This interaction causes anti-inflammatory, antiproliferative, and vasodilatory effects. Ang II also binds to $\mathrm{AT}_{2} \mathrm{R}$ to mediate vasodilatory effects. The expression of $\mathrm{AT}_{2} \mathrm{R}$ is low in the cardiovascular system of healthy adults (Arendse et al. 2019; Cheng et al. 2020). In the case of hypotension, the classical RAS axis plays an important role. The ACE2 antagonizes these effects through the negative regulatory RAS axis, thus preventing many diseases like hypertension, diabetes, and CVD (Cheng et al. 2020; Tikellis et al. 2011). The Ang II elicits downstream pathophysiological effects, it could be the primary cause for the symptoms of the COVID-19 and SARS disease. However, a partial neutralization of Ang II could be an effective way to treat the disease and not entirely prohibiting its function as a vasoconstrictor. ACE2 knock out (KO) mice developed mild liver fibrosis and promote migration of inflammatory cells, when wild type (WT) and ACE2KO mice were subjected to different acute and chronic type lung injury, this study implies that ACE2 inhibits the liver fibrosis. Subsequently, ACE2-KO mice were treated with recombinant $\mathrm{ACE} 2$, which could terminate the fibrosis during the cholestatic liver injury. Hence, ACE2 acts as a RAS antagonist, to inhibit liver fibrosis by degrading Ang II and forming Ang 1-7. The absence of ACE2 activity augments liver fibrosis in chronic liver injury models, and recombinant ACE2 could have a therapeutic effect in this regard (Österreicher et al. 2009). Figure 4 represents the physiological role of ACE and ACE2 in the RAS pathway.

\section{ACE2 expression in human tissues}

ACE2 is highly expressed in the heart, lungs, kidney, testis, and GI tract (Turner et al. 2004; Chen et al. 2020). ACE2 is abundantly present and has high level of activity in human epithelial AT2 cells, small intestinal epithelial cells, endothelial cells of arteries and veins, and smooth muscle cells of arteries. It was expressed in the Stratum Basale of the non-keratinized squamous epithelium of nasal, oral mucosa, and nasopharynx and basal cell layer of skin. In contrast, a lower expression level is reported in glomerular tubules, while expression is absent in glomerular endothelial and glomerular mesangial cells. ACE2 expression has not been indicated in B cell, T cells, macrophages, Kupffer cells, and liver cells, and tissues such as bone marrow, spleen, thymus, and lymph (Hamming et al. 2004; Santos et al. 2018). Higher expression of ACE2 is observed in tissue than in plasma and varies between different ages and sex. Aging factor also plays an essential role in ACE2 expression, in which chances of COVID-19 rise with increasing age. Also, it has been reported that females have higher ACE2 expression compared to males (Haber et al. 2014; Xudong et al. 2006). The ACE2 at the gene level is expressed in almost all the organs and tissues (Table 4). The IHC studies and microarray-based gene expression data demonstrate the ACE2 expression in glandular cells of the adrenal gland, colon, gall bladder, and small intestine. The higher expression of ACE2 is observed in testis, small intestine, heart, kidney, colon, and adipose tissues, whereas tubular cells in the kidney and seminiferous ducts of testis have the highest expression of ACE2.

Moreover, the ACE2 protein expression is also found in the heart and kidney. The ACE2 gene expresses in the colon and adipose tissue, but corresponding protein expression is not observed. A positive ACE2 gene expression was observed in organs such as tongue, salivary gland, and lungs that serve a significant route of viral entry (Table 4), thus posing a higher risk of infection. Fluidic secretions from the body like pancreatic juice and urine have higher protein expression of ACE2 (probably soluble form), signifying a higher viral load. The fetal gut and heart have significant ACE2 protein expression, indicates possibility to have a higher risk of viral infection. Ovaries have the highest expression levels followed by kidney, heart, gall bladder, and testis. Urine and fecal discharge from the infected patients would cause virus spread and must thoroughly investigate. The clinical data analysis indicates that COVID-19 patients tested positive due to the presence of SARS-CoV-2 in feces and urine (Wang et al. 2020), indicating the possibility that the GI tract might have abundant ACE2 protein expression as observed in gall bladder and pancreatic juice along with kidney and testis (Table 4).

Furthermore, the ACE2 protein expression is high in cancers of stomach, liver, colon, renal system, and urothelium (Table 4). Comparatively, diseased conditions like cancer, heart disorders, diabetes, and smoking associated ailments have higher ACE2 gene and protein expression on tissues than seen in healthy individuals (Table 4) (Chen 
Table 4 ACE2 gene and protein expression levels in various organs, cells, and tissues in human body. (Source: IHC and microarray data of normal cells and cancer cell expression data obtained from: https://

\begin{tabular}{|c|c|c|c|c|c|c|}
\hline \multirow[t]{2}{*}{ Tissues/organs } & \multirow[t]{2}{*}{ Cells } & \multicolumn{3}{|l|}{ Gene expression } & \multicolumn{2}{|c|}{ Protein expression } \\
\hline & & $\begin{array}{l}\text { Human Protein Atlas } \\
\text { (based on IHC and } \\
\text { microarray) }\end{array}$ & $\begin{array}{l}\text { Gene card } \\
\text { RNA-Seq } \\
\text { expression }\end{array}$ & $\begin{array}{l}\text { Gene card } \\
\text { Microarray } \\
\text { data }\end{array}$ & Gene card & $\begin{array}{l}\text { Human Protein Atlas } \\
\text { Cancer cell expres- } \\
\text { sion }\end{array}$ \\
\hline Adipose tissue & Adipocytes & - & ++ & NA & - & NA \\
\hline \multirow[t]{2}{*}{ Adrenal gland } & Glandular cells & + & + & NA & - & NA \\
\hline & Adrenal cortex & NA & NA & + & & \\
\hline Amniocyte & - & NA & NA & NA & - & NA \\
\hline Amygdala & - & NA & NA & + & NA & NA \\
\hline \multirow[t]{2}{*}{ Appendix } & Glandular cells & - & NA & + & NA & NA \\
\hline & Lymphoid tissue & & & & NA & \\
\hline Artery & - & NA & + & NA & NA & NA \\
\hline \multirow[t]{4}{*}{ Blood } & Serum & NA & + & NA & - & NA \\
\hline & Plasma & & & & & \\
\hline & Neutrophil & & & & & \\
\hline & Platelets & & & & & \\
\hline \multirow[t]{5}{*}{ Bone } & $\begin{array}{l}\text { Skeletal muscle } \\
\text { (myosites) }\end{array}$ & NA & + & NA & - & NA \\
\hline & Synovial fluid & NA & NA & & & \\
\hline & $\begin{array}{l}\text { Bone marrow hemat- } \\
\text { opoietic cells }\end{array}$ & - & & & & \\
\hline & $\begin{array}{l}\text { Bone marrow mesen- } \\
\text { chymal stem cells }\end{array}$ & NA & & & & \\
\hline & $\begin{array}{l}\text { Bone marrow stromal } \\
\text { cells }\end{array}$ & & & & & \\
\hline Brain & - & NA & + & NA & - & NA \\
\hline \multirow[t]{4}{*}{ Breast } & Adipocytes & - & + & NA & - & - \\
\hline & Glandular cells & & & & & \\
\hline & Myoepithelial cells & & & & & \\
\hline & Milk & NA & NA & & & \\
\hline Cardia & - & NA & NA & NA & - & NA \\
\hline \multirow[t]{2}{*}{ Caudate } & Glial cells & - & NA & NA & NA & NA \\
\hline & Neuronal cells & & & & & \\
\hline \multirow[t]{3}{*}{ Cerebellum } & Cells in granular layer & - & + & NA & NA & NA \\
\hline & Cells in molecular layer & & & & & \\
\hline & Purkinje cells & & & & & \\
\hline Cerebellar peduncles & - & NA & NA & + & NA & NA \\
\hline \multirow[t]{4}{*}{ Cerebral cortex } & Endothelial cells & - & + & NA & - & NA \\
\hline & Glial cells & & & & & \\
\hline & Neuronal cells & & & & & \\
\hline & Neuropil & & & & & \\
\hline Cerebrospinal fluid & - & NA & NA & NA & - & NA \\
\hline
\end{tabular}

www.proteinatlas.org/about/download; Gene Card RNA, microarray and protein data obtained from: (GCID: GC0XM015562)) 
Table 4 (continued)

\begin{tabular}{|c|c|c|c|c|c|c|}
\hline \multirow[t]{2}{*}{ Tissues/organs } & \multirow[t]{2}{*}{ Cells } & \multicolumn{3}{|l|}{ Gene expression } & \multicolumn{2}{|c|}{ Protein expression } \\
\hline & & $\begin{array}{l}\text { Human Protein Atlas } \\
\text { (based on IHC and } \\
\text { microarray) }\end{array}$ & $\begin{array}{l}\text { Gene card } \\
\text { RNA-Seq } \\
\text { expression }\end{array}$ & $\begin{array}{l}\text { Gene card } \\
\text { Microarray } \\
\text { data }\end{array}$ & Gene card & $\begin{array}{l}\text { Human Protein Atlas } \\
\text { Cancer cell expres- } \\
\text { sion }\end{array}$ \\
\hline \multirow[t]{6}{*}{ Cervix (uterine) } & Glandular cells & - & + & NA & - & - \\
\hline & $\begin{array}{l}\text { Squamous epithelial } \\
\text { cells }\end{array}$ & - & & & & \\
\hline & Cervix & NA & & & & \\
\hline & $\begin{array}{l}\text { Endometrial stromal } \\
\text { cells }\end{array}$ & - & & & & - \\
\hline & $\begin{array}{l}\text { Endometrial glandular } \\
\text { cells }\end{array}$ & - & & & & \\
\hline & Uterus corpus & NA & & + & NA & NA \\
\hline Ciliary ganglion (eyes) & - & NA & NA & + & NA & NA \\
\hline Cingulate cortex & - & NA & NA & + & NA & NA \\
\hline \multirow[t]{4}{*}{ Colon } & Glandular cells & + & ++ & NA & - & + \\
\hline & Endothelial cells & - & & & & \\
\hline & $\begin{array}{l}\text { Peripheral nerve/gan- } \\
\text { glion }\end{array}$ & - & & & & \\
\hline & Colon muscle & NA & & & & \\
\hline Caudate nucleus & - & NA & NA & + & NA & NA \\
\hline Dorsal root ganglion & - & NA & NA & + & NA & NA \\
\hline Endothelial & - & NA & NA & + & NA & NA \\
\hline Epididymis & Glandular cells & - & NA & NA & NA & NA \\
\hline Esophagus & $\begin{array}{l}\text { Squamous epithelial } \\
\text { cells }\end{array}$ & - & + & $\mathrm{NA}$ & - & NA \\
\hline Fetal brain & - & NA & NA & + & - & NA \\
\hline Fetal gut & - & NA & NA & NA & ++ & NA \\
\hline Fetal heart & - & NA & NA & NA & + & NA \\
\hline Fetal liver & - & NA & NA & + & - & NA \\
\hline Fetal lung & - & NA & NA & + & - & NA \\
\hline Fetal ovary & - & NA & NA & NA & - & NA \\
\hline Fetal testis & - & NA & NA & NA & - & NA \\
\hline Fetal thyroid & - & NA & NA & + & NA & NA \\
\hline Fallopian tube & Glandular cells & - & NA & NA & NA & NA \\
\hline Gallbladder & Glandular cells & +++ & + & NA & + & NA \\
\hline Globus pallidus & - & NA & NA & + & NA & NA \\
\hline Hair follicle & - & NA & NA & NA & - & NA \\
\hline Head an neck & - & NA & NA & NA & NA & - \\
\hline \multirow[t]{3}{*}{ Heart } & Cardiac myocytes & - & ++ & + & ++ & NA \\
\hline & $\begin{array}{l}\text { Atrioventricular node } \\
\text { cells }\end{array}$ & NA & & + & & \\
\hline & Heart muscle & - & & NA & & \\
\hline \multirow[t]{2}{*}{ Hippocampus } & Glial cells & - & NA & NA & NA & NA \\
\hline & Neuronal cells & & NA & NA & & \\
\hline Hypothalamus & - & NA & NA & + & NA & NA \\
\hline
\end{tabular}


Table 4 (continued)

\begin{tabular}{|c|c|c|c|c|c|c|}
\hline \multirow[t]{2}{*}{ Tissues/organs } & \multirow[t]{2}{*}{ Cells } & \multicolumn{3}{|l|}{ Gene expression } & \multicolumn{2}{|c|}{ Protein expression } \\
\hline & & $\begin{array}{l}\text { Human Protein Atlas } \\
\text { (based on IHC and } \\
\text { microarray) }\end{array}$ & $\begin{array}{l}\text { Gene card } \\
\text { RNA-Seq } \\
\text { expression }\end{array}$ & $\begin{array}{l}\text { Gene card } \\
\text { Microarray } \\
\text { data }\end{array}$ & Gene card & $\begin{array}{l}\text { Human Protein Atlas } \\
\text { Cancer cell expres- } \\
\text { sion }\end{array}$ \\
\hline \multirow[t]{7}{*}{ Immune cells } & Myeloid & NA & NA & + & NA & NA \\
\hline & Dendritic cells & & & & & \\
\hline & Monocytes & & & & - & \\
\hline & NK Cells & & & & & \\
\hline & T CD4+ cells & & & & & \\
\hline & T CD8+ cells & & & & & \\
\hline & B-cells & & & & & \\
\hline \multirow[t]{2}{*}{ Kidney } & Cells in tubules & +++ & ++ & NA & ++ & +++ \\
\hline & Cells in glomeruli & - & & & & \\
\hline \multirow[t]{3}{*}{ Liver } & Bile duct cells & - & + & NA & - & + \\
\hline & Hepatocytes & & & & & \\
\hline & Liver secratome & NA & & & & \\
\hline \multirow[t]{4}{*}{ Lung } & Bronchial epithelium & NA & + & + & - & - \\
\hline & $\begin{array}{l}\text { Respiratory epithelial } \\
\text { cells }\end{array}$ & - & & NA & & \\
\hline & Macrophages & & & & & \\
\hline & Pneumocytes & & & & & \\
\hline Lung alveolar lavage & - & NA & NA & NA & - & NA \\
\hline \multirow[t]{3}{*}{ Lymph } & Germinal center cells & - & + & NA & - & - \\
\hline & Lymph node & & & & & \\
\hline & $\begin{array}{l}\text { Non-germinal center } \\
\text { cells }\end{array}$ & & & & & \\
\hline Medulla oblongata & - & NA & NA & + & NA & NA \\
\hline Nasopharynx & $\begin{array}{l}\text { Respiratory epithelial } \\
\text { cells }\end{array}$ & - & NA & NA & - & NA \\
\hline Occipital lobe (brain) & - & NA & NA & + & NA & NA \\
\hline Olfactory bulb & - & NA & NA & + & NA & NA \\
\hline \multirow[t]{2}{*}{ Oral mucosa } & $\begin{array}{l}\text { Squamous epithelial } \\
\text { cells }\end{array}$ & - & NA & NA & NA & NA \\
\hline & Oral epithelium & NA & NA & & - & NA \\
\hline \multirow[t]{2}{*}{ Ovary } & Follicle cells & - & + & NA & +++ & - \\
\hline & Ovarian stroma cells & & & & & \\
\hline \multirow[t]{3}{*}{ Pancreas } & $\begin{array}{l}\text { Exocrine Glandular } \\
\text { Cells }\end{array}$ & - & + & NA & NA & - \\
\hline & Islets of langerhans & & & + & - & \\
\hline & Pancreatic juice & NA & & NA & +++ & \\
\hline Parathyroid gland & Glandular cells & - & NA & & NA & NA \\
\hline Parietal lobe (brain) & - & NA & NA & + & NA & NA \\
\hline Pineal gland & - & NA & NA & + & NA & NA \\
\hline Pituitary & - & NA & + & + & NA & NA \\
\hline \multirow[t]{2}{*}{ Placenta } & Decidual cells & - & NA & NA & NA & NA \\
\hline & Trophoblastic cells & & & & & \\
\hline Pons & - & NA & NA & + & NA & NA \\
\hline Prefrontal cortex & - & NA & NA & + & NA & NA \\
\hline Prostate & Glandular cells & - & + & NA & - & - \\
\hline Rectum & Glandular cells & + & NA & NA & - & + \\
\hline
\end{tabular}


Table 4 (continued)

\begin{tabular}{|c|c|c|c|c|c|c|}
\hline \multirow[t]{2}{*}{ Tissues/organs } & \multirow[t]{2}{*}{ Cells } & \multicolumn{3}{|l|}{ Gene expression } & \multicolumn{2}{|c|}{ Protein expression } \\
\hline & & $\begin{array}{l}\text { Human Protein Atlas } \\
\text { (based on IHC and } \\
\text { microarray) }\end{array}$ & $\begin{array}{l}\text { Gene card } \\
\text { RNA-Seq } \\
\text { expression }\end{array}$ & $\begin{array}{l}\text { Gene card } \\
\text { Microarray } \\
\text { data }\end{array}$ & Gene card & $\begin{array}{l}\text { Human Protein Atlas } \\
\text { Cancer cell expres- } \\
\text { sion }\end{array}$ \\
\hline Retina (eyes) & - & NA & NA & NA & - & NA \\
\hline Salivary gland & $\begin{array}{l}\text { Glandular cells } \\
\text { Saliva }\end{array}$ & $\begin{array}{l}- \\
\mathrm{NA}\end{array}$ & $\begin{array}{l}+ \\
\text { NA }\end{array}$ & NA & - & NA \\
\hline Seminal vesicle & Glandular cells & + & NA & NA & NA & NA \\
\hline Skin & $\begin{array}{l}\text { Fibroblasts } \\
\text { Keratinocytes } \\
\text { Langerhans } \\
\text { Melanocytes } \\
\text { Epidermal cells }\end{array}$ & - & NA & NA & - & - \\
\hline Small intestine & $\begin{array}{l}\text { Glandular cells } \\
\text { Duodenal glandular } \\
\text { cells }\end{array}$ & +++ & +++ & NA & NA & NA \\
\hline Smooth muscle & Smooth muscle cells & - & NA & NA & NA & NA \\
\hline Soft tissue & $\begin{array}{l}\text { Chondrocytes } \\
\text { Fibroblasts } \\
\text { Peripheral nerve } \\
\text { Fibroblasts } \\
\text { Peripheral nerve }\end{array}$ & - & NA & NA & NA & NA \\
\hline Spinal chord & - & NA & + & NA & - & NA \\
\hline Spleen & $\begin{array}{l}\text { Cells in red pulp } \\
\text { Cells in white pulp }\end{array}$ & - & + & NA & - & NA \\
\hline Stomach & $\begin{array}{l}\text { Glandular cells } \\
\text { Glandular cells }\end{array}$ & - & + & NA & - & + \\
\hline Subthalamic nucleus & - & NA & NA & + & NA & NA \\
\hline Sup cervical ganglion & - & NA & NA & + & NA & NA \\
\hline Temporal lobe (brain) & - & NA & NA & + & NA & NA \\
\hline Testis & $\begin{array}{l}\text { Cells in seminiferous } \\
\text { ducts } \\
\text { Leydig cells } \\
\text { Interstitial cells } \\
\text { Germ cells }\end{array}$ & NA & +++ & $\begin{array}{l}+++ \\
+\end{array}$ & + & - \\
\hline Thalamus & - & NA & NA & + & NA & NA \\
\hline Thyroid gland & Glandular cells & - & + & NA & - & - \\
\hline Tibial nerve & - & NA & + & NA & NA & NA \\
\hline Tongue & - & NA & NA & + & - & NA \\
\hline Tonsil & $\begin{array}{l}\text { Germinal center cells } \\
\text { Non-germinal center } \\
\text { cells } \\
\text { Squamous epithelial } \\
\text { cells }\end{array}$ & - & NA & + & - & NA \\
\hline Trachea & - & NA & NA & + & NA & NA \\
\hline Trigeminal ganglion & - & NA & NA & + & NA & NA \\
\hline Urinary bladder & Urothelial cells & - & NA & NA & - & + \\
\hline urine & - & NA & NA & NA & +++ & NA \\
\hline Vagina & $\begin{array}{l}\text { Squamous epithelial } \\
\text { cells }\end{array}$ & - & NA & NA & NA & NA \\
\hline Vitrious humor & - & NA & NA & NA & - & NA \\
\hline
\end{tabular}

IHC immunohistochemistry, RNA-Seq RNA sequencing, $N A$ not available, +++: highest expression, ++: moderate expression, +: lower expression; -: no/negative expression 
et al. 2020; Uhlen et al. 2017; Brake et al. 2020; Nicin et al. 2020). Therefore, the COVID-19 patients suffering from these comorbidities have higher risks of infection, it may lead to severe conditions. The transcriptome analysis of 700 comorbid COVID-19 patients' lung samples indicate that the higher ACE2 expression in these patients than control. This data suggests that individuals indicating such comorbid SARS-CoV-2 infections may have chances of developing severe COVID-19 conditions (Pinto et al. 2020). A higher ACE2 protein expression facilitates higher viral load, therefore cells lacking ACE2 can find a possible treatment option against COVID-19. Recently, convalescent plasma from recovered patients was used to treat four critically ill COVID-19 patients, including a pregnant woman, and all four recovered eventually, though its efficacy has to be further investigated (Zhang et al. 2020c). It is also suggested that immune cells like monocytes, NK cells, B-cells, and T cells have no ACE2 protein expression (Table 4), would be used instead of plasma therapy from recovered patients.

\section{Effects of COVID-19 on human tissues}

The viral infection reduces the activity of ACE2, which triggers an imbalance of the Ang II/ACE2 regulation system and led to the accumulation of Ang II (Cheng et al. 2020).

\section{SARS-CoV-2 infection in liver}

Both liver and bile duct cells have ACE2 expression, but the expression is higher in bile duct cells than in liver cells. The bile duct epithelial cells play a crucial role in immune responses and liver generation. However, COVID19 patients suffered from a liver injury more commonly in case of infection that damages the bile duct's cells rather than liver (Xu et al. 2020; Chai et al. 2020; Banales et al. 2019; Liu et al. 2020c).

\section{SARS-CoV-2 infection in lungs}

ARDS is the most severe condition of lung injury and has a high mortality rate (Ware and Matthay 2000). Diseases like SARS-CoV infection, HIV, and Bird flu may cause sepsis, aspiration, and pneumonia (Cheng et al. 2020). These diseases directed to elevate pulmonary vascular permeability and pulmonary oedema, ultimately causing ARDS (Gonzales et al. 2015). ACE2 is highly expressed in the lung and has a protective effect in acute lung injury (Imai et al. 2005). The lungs' alveoli consist of a majority of AT1 cells (95\%) (mainly constitutes alveolar surface for gas exchange and play a key role in maintaining permeability barrier function of alveolar membrane (Gurka and Balk 2008)), and very few AT2 cells (5\%). AT2 cells play a crucial role in maintaining lung elasticity by producing pulmonary surfactant that monitors cellular functions through specific protein-protein, lipid-protein, and lipid-lipid interactions. Further, these alveolar stem cells act as progenitor for AT1 and perform function in gas exchange (Aoshiba et al. 2003; Beers and Moodley 2017; Mason and Dobbs 1980; Pérez-Gil 2008). Since ACE2 expresses in mucosal and AT2 cells in the lungs and alveoli, therefore, SARS-CoV-2 targets AT2 cells and also damages the regenerative capacity of lung AT1 cells. Reduced levels of AT2 cells led to lung damage as there would be surfactant deficiency, causing fibrotic obliteration and only partial repair of alveolar epithelial injury (Rivellese and Prediletto 2020; Barkauskas et al. 2013). The virus may also downregulate ACE2, leading to toxic overaccumulation of Ang II, thus inducing ARDS (Hanff et al. 2020).

\section{SARS-CoV-2 infection in intestine}

The SARS-CoV-2 infection in the gastrointestinal (GI) tract causes GI disorders (showing prominent symptoms of nausea, vomiting and/or diarrhea), and are common in severe COVID-19 patients compared to mild cases (Jin et al. 2020b). Clinical data of 651 COVID-19 patients in China showed that about $11 \%$ of patients had GI disorders, most commonly diarrhea in 5-8\% patients which persisted for an average of 4 days before the onset of respiratory symptoms. Another study conducted in China and Hong Kong reported that of the total COVID-19 patients considered in the study, with a sample size of $1099,138,58$, 204,59 , and 254 , the section of patients showing in GI disorders are $8.7 \%, 13.7 \%, 11 \%, 18.6 \%, 25.4 \%$ and $26 \%$ respectively. While in United States and Europe, $61 \%$ and $35 \%$ patients in the former, and 55\% patients in the latter among a total of 318,278 , and 40 COVID-19 patients respectively, showed GI disorder signs and symptoms (Guan et al. 2020; Wang et al. 2020; Lin et al. 2020; Pan et al. 2020; Cheung et al. 2020; Zhou et al. 2020b; Redd et al. 2020; Nobel et al. 2020; Effenberger et al. 2020; Trottein and Sokol 2020). Moreover, the presence of the SARS-CoV-2 virus in the stool samples indicated that the virus could also infect the GI tract (Guan et al. 2020; Holshue et al. 2020). A study identified the presence of SARS-CoV-2 RNA in 29\% of specimens that indicates positive results for COVID-19 in stool specimen (Wang et al. 2020). In addition, SARS-CoV-2 infectivity is higher in GI tract compared to lungs (Ma et al. 2020b). The viral infection in the intestinal cell may be due to the high 
expression of ACE2 in the small intestine colon (Table 4) (Hamming et al. 2004).

There could be various factors attributed to GI tract disorders in COVID-19 patients. During the infection, the release of inflammatory cytokines may weaken the epithelial barrier. High viral load and replication in the GI tract may damage the gut epithelium. The GI symptoms may also be due to dysregulation of the ACE2-RAS mechanism (Trottein and Sokol 2020). However, the actual cause of GI disorders in COVID-19 patients is yet to be studied.

\section{SARS-CoV-2 infection in the heart}

Downregulation of ACE2 and toxic Ang II overaccumulation in COVID-19 patient causes fulminant myocarditis (Zhonghua et al. 2020). Nonetheless, Cardiovascular disease (CVD) and pharmacologic RAS inhibition both increase the levels of ACE2 expression. Increased ACE2 expression provides easier viral entry, which may increase the virulence of SARS-CoV-2 in the lungs and heart (Imai et al. 2005; Crackower et al. 2002; Kuba et al. 2005). The virus has potential susceptibility to infect the heart as ACE2 expression is observed in the cardiac muscle cells, higher than in the lungs, but lower than that in the intestine and kidney (Table 4). Patients with primary heart failure may have higher chances of having a heart attack and severe repercussions in case of the viral infection as they exhibit higher ACE2 expression at both mRNA and protein levels (Table 4). ACE2 is also highly expressed in pericytes of adult human hearts. Pericytes play a crucial role in maintaining endothelial cell function in capillary vessels (Chen et al. 2020). Over-accumulation of Ang II can cause an inflammatory response of cells, promoting oxidative stress and migration of vascular smooth muscle and endothelial cells and causing atherosclerosis (Chen et al. 1998).

Moreover, ACE2 is mainly involved in the RAS pathway and acts as an essential factor in heart function. However, in hypertensive rats, ACE2 mRNA and protein expression was significantly declined, signifying that it is a crucial gene for this quantitative trait locus (QTL). The disruption in ACE2 expression may lead to cardiac contractility disorder and increased Ang II expression, with upregulation of genes inducing hypoxia in the heart muscles (Crackower et al. 2002).

\section{SARS-CoV-2 infection in the reproductive system}

A recent clinical study for the presence of SARS-CoV-2 in semen samples has shown that 6 out of 38 patients were COVID-19 positive ( $\mathrm{Li}$ et al. 2020). This could be due to high ACE2 gene expression and presence of the transcribed protein in low amounts in the Testis (Table 4). However, in oocytes of two female COVID-19 patients, the presence of SARS-CoV-2 RNA was undetectable, and the further clinical investigation is yet to be performed (Barragan et al. 2020). It has been reported that male SARS-CoV-2 infected patients had reduced sperm count and sperm motility, and asymptomatic female patients developed respiratory symptoms postpartum (Segars et al. 2020). Transcriptome sequencing data indicated ACE2 expression in the germ cells, Leydig and Sertoli cells of the testis, and infection of SARS-CoV-2 virus may cause impairment of male fertility (Vishvkarma and Rajender 2020). ACE2 transcripts were also observed in human spermatogonia, spermatocyte, and spermatids in 500 individual cells through laser-dissection, micro-capture followed by RNA sequencing (Jan et al. 2017). Apparently, to high expression of ACE2, as observed in testis, could increase the risk of SARS-CoV-2 infection (Table 4). This is in contradiction to the low expression of ACE2 and TMPRSS2 observed in the female reproductive organs like ovaries, fallopian tube, uterus, and myometrium that indicates to have a lower susceptibility for SARS-CoV-2 infection (Goad et al. 2020).

\section{Target based current approaches for COVID-19 treatment}

Presently, various approaches have come up to combat COVID-19 pandemic. However, effective treatment against SARS-CoV-2 are still under investigation. Treatments targeting host cellular receptors such as ACE2 based therapies, recombinant RBD, soluble ACE2 therapy, and inhibitors targeting other human cellular receptors like CD147, TMPRSS2, trypsin and cathepsin could serve as effective ways to overcome SARS-CoV-2 infection.

\section{ACE2 based therapies}

As ACE2 serves to be receptor for entry of SARS-CoV and SARS-CoV-2, targeting this receptor would help preventing viral entry along with mitigating the adverse effects of infection. Therefore, use of ACE blockers and MSCs based therapy could be a practical approach for the treatment of COVID-19 patients.

\section{Use of ACE blocker}

RAS inhibitors like ACEi and ARBs have been used to diminish the unfavorable effects of Ang II. These inhibitors are used for the treatment of CVD, hypertension, and diabetes (Arendse et al. 2019; Sparks et al. 2020). According 
to the National Health and Nutrition Examination Survey's current analysis, these are the widely used and prevalent classes of antihypertensive agents (Derington et al. 2020; Vuille-Dit-Bille et al. 2015). ACEi inhibits the enzyme ACE, thereby decreasing the production of Ang II (Miller and Arnold 2019). They also increase levels of Ang 1-7 and Ang 1-9 for reducing hypertension and protect the cardiovascular system as ACE helps in the degradation of Ang 1-7. Since ACE and ACE2 are different enzymes, thus, ACEi does not inhibit ACE2. These inhibitors increase renin secretion as well as the flux through RAS by suppressing counterregulatory RAS. This causes declination of pharmacologic efficacy of ACEi in the long-term treatment, wherein Ang II is not entirely inhibited, and abundant Ang I is present due to renin's high activity in the blood plasma. Hence, a new steady state is established where there is no Ang II suppression, while higher Ang 1-7 levels is present (Arendse et al. 2019; Lindholm et al. 2002; McMurray et al. 2003; Dahlöf et al. 2002; Pitt et al. 2000). Animal studies have shown that ACEi and ARBs upregulate the expression of ACE2, which would also aggravate SARS-CoV-2 infection (Danser et al. 2020; Talreja et al. 2020), but the studies vary due to various ARBs in different tissues. Clinically, it has been investigated that ACEi treatment in healthy human increases the ACE2 duodenal mRNA expression level compared with control (Vuille-Dit-Bille et al. 2015). ARBs (Azilsartan, Losartan, Telmisartan, and Olmesartan) have been known to increase ACE2 mRNA and protein expression in other animal models with heart and chronic kidney disorders (Iwanami et al. 2014; Kai and Kai 2020; Sukumaran et al. 2011, 2012a, b, 2017; Ishiyama et al. 2004; Lakshmanan et al. 2012). Conversely, Ramipril and Valsartan, independently or in co-treatment, did not affect cardiac ACE2 expression in case of myocardial infarction (Burchill et al. 2012). The ARB treatment to patients shows no significant change in the expression level of ACE2 (Vuille-Dit-Bille et al. 2015). Few reports demonstrated that ACEis/ARBs were able to reduce the harsh effects of COVID-19. The impact of ACEi and ARBs in higher doses is analyzed in the animal models, while in clinical trials the dosage given is comparatively low (Kai and Kai 2020). This results in certain conflicting opinions among physicians and patients about the treatment of COVID-19 with ACEis/ARBs (Sparks et al. 2020).

On the contrary, significant ACE2 mRNA upregulation was observed in the heart with ACEis and ARB's treatment, suggesting that these inhibitors may cause detrimental effects on COVID-19 (Ferrario et al. 2005). The COVID19 patients with comorbidities are being treated with drugs that perhaps stimulate ACE2 expression, which in turn increases the risk of developing severe and fatal conditions of COVID-19 infection and are likely to be investigated further. Likewise, ACEi and ARB increase ACE2 expression, hence increasing the viral load (Peiris et al. 2003), but also need to be investigated clinically (Chen et al. 2020). There are two issues associated with heart diseases (Guo et al. 2020). First, SARS-CoV-2 infection is aggravated in pulmonary tissues due to the upregulated expression of ACE2. Second, downregulation of ACE2 occurs after the infection and symptoms of ARDS arise, which is in contradiction to the first issue. This suggests that administering patients with ACEis/ARBs would increase the viral infection risk factor, and once infected, ACE2 downregulation would be a distinctive feature of COVID-19 progression. Hitherto, no substantial evidence has been reported in supporting the link between RAS inhibition and increased ACE2 expression that led to enhanced infection and virulence of SARS-CoV-2 (Sparks et al. 2020).

Therefore, COVID-19 could be affected by RAS inhibition, but the pathway of impact is ambiguous; it may decrease the pro-inflammatory activity of Ang II. Subsequently, the risk of ARDS, myocarditis, or mortality in COVID-19 or RAS inhibition, may increase ACE2 expression, leading to the enhanced virulence of SARS-CoV-2 in the lungs and heart, eventually causing ARDS, myocarditis, and death (Hanff et al. 2020). Therefore, the current evidence does not link COVID-19 and hypertension to ACEi and ARB medication and is subject to vary. Hence, it is dubious to conclude that these drugs enhance ACE2 expression and its activity in tissues to cause the viral infection to be critical (Talreja et al. 2020).

SARS-CoV-2's S-protein binds to ACE2 that leads to internalization and shedding of ACE2 into a soluble form. It causes increased Ang II, thereby declining Ang (1-7), which increases net inflammation and fibrosis. On the contrary, when treated with ACEis and ARBs, they can induce alterations in RAS. ACEi can inhibit Ang I, and converted into Ang II, while ARB inhibit the activity of $\mathrm{AT}_{1} \mathrm{R}$. Subsequently, the residual Ang II bind to $\mathrm{AT}_{2} \mathrm{R}$, and Ang (1-7), which further bind to the MasR pathway by diminishing the effects of Ang II and increase the Ang (1-7) levels leading to attenuated inflammation and fibrosis (Sparks et al. 2020).

\section{MSCs based therapy}

MSCs are adult tissue-derived multipotent cells having the property of self-renewal and differentiation into various types of cells (Hayes et al. 2012). MSCs perform immunomodulatory effects by releasing various cytokines through paracrine secretions and interacting with immune cells (Galipeau and Sensébé 2018; Bernardo and Fibbe 2013). These properties of MSCs make it a suitable candidate in cellbased therapy and have been used for treatment to reverse the cytokine storm (Leng et al. 2020).

A study was conducted on seven COVID-19 patients infused with MSCs for two days. This shows a significant improvement in lung functions after 14 days. It was also 
observed that three patients in which one was critically infected were able to recover within ten days of the MSCs treatment. There was an increase in the level of peripheral blood lymphocytes, like $\mathrm{CXCR} 3^{+} \mathrm{CD} 4^{+}$and $\mathrm{CD} 8^{+} \mathrm{T}$ cells, while CXCR3 NK cell level was diminished in 3-6 days of treatment. The levels of TNF- $\alpha$ were reduced while IL-10 levels stayed elevated. Concluding that, MSCs could be used for effective treatment in SARS-CoV-2 infected patients (Leng et al. 2020).

The in vitro and in vivo studies suggest that bone marrow MSCs could differentiate and exhibit specific pulmonary epithelial cells (Krause et al. 2001; Li et al. 2012). Preclinical investigation on mice revealed that bone marrow-derived MSCs reduces the pulmonary vascular permeability, normalized lung endothelial nitric oxide synthase (eNOS), and enhanced the integrity of the endothelial barrier compared to control (He et al. 2015). The study demonstrated that ACE2 transduced MSCs in lipopolysaccharide (LPS) inducedacute lung injury (ALI) treated mice were able to increase the expression and activity of ACE2, thereby reducing the level of Ang II and elevated Ang 1-7 and diminishing the adverse effects of Ang II with an overall improvement of pulmonary endothelial function (He et al. 2015). Similarly, the mice were pre-treated with bleomycin followed by ACE2 gene expressing umbilical cord derived MSCs (uMSCs) treatment mitigated the lung damage having better efficacy than ACE2 or uMSCs alone. Nonetheless, noted a reduced expression of malondialdehyde (MDA), TNF- $\alpha$, oxidized glutathione (GSSG), interferon (IFN) $-\gamma$, transforming growth factor (TGF)- $\beta$, IL-1, IL-2, IL-6, MMPs, hydroxyproline, tissue inhibitors of metalloproteinases (TIMPs), and collagen type $1 \mathrm{mRNA}$. Subsequently, this increases the level of superoxide dismutase (SOD), Glutathione (GSH), ACE2, and IL-10. Since uMSCs are accessible and have the least ethical issues than bone marrow-derived MSCs, they are convenient for therapeutic purposes for ARDS/ ALI (Min et al. 2015).

Currently, enough clinical data is not present regarding the use of MSCs in viral-induced ARDS, making it challenging for its use. Furthermore, the production and use of current Good Manufacturing Practice (cGMP) grade MSCs has major limitations, first, lack of cost effectiveness makes this therapy more expensive. Second, in this regard, limited number of clinical has been reported (Golchin 2020; Khoury et al. 2020). However, technological improvements, adequate clinical reports, and the nations' economic sustainability can overcome such limitations.

\section{Recombinant RBD binding to ACE2}

ACE2 is a common receptor for SARS-CoV and SARSCoV-2 RBD binding (Zhou et al. 2020a), it can act as the primary target for inhibitors, antibodies, and vaccines. The recombinant RBD of SARS-CoV-2 S-protein has a strong binding affinity with human ACE2 (hACE2) and bat ACE2 (bACE2 (Tai et al. 2020)), and it's transfection prevents the viral entry into hACE2 expressing cells. The studies also demonstrated that polyclonal antibodies specific to RBD of SARS-CoV cross-reacted with the RBD of SARS-CoV-2, indicating that these antibodies could also be effective against the SARS-CoV-2 (Tai et al. 2020). The recombinant RBD could serve as an attractive vaccine target, and there could be a chance of low immunogenicity. This could be optimized by incorporating appropriate adjuvants or selecting potent target sequences that would elicit good immune response (Wang et al. 2020; Dai et al. 2020).

\section{Soluble ACE2 and Cyclodextrin complex therapy targets viral domains}

The soluble ACE2 (sACE2) retain the enzymatic activity of the membrane-bound ACE2 and interact with SARS-CoV S-protein (Hong et al. 2009). The sACE2 suppresses the effect of SARS-CoV, whereas SARS-CoV and SARS-CoV-2 follow the same infectivity mechanism, thus it is hypothesized that sACE2 would likely suppress the SARS-CoV-2 infection. Also, sACE2 used to treat ALI and reduces the mortality as prolonged coronavirus infection leading to the downregulation of ACE2, causing ARDS and pulmonary oedema. It can also promote the expression of ACE2 in the heart, kidney, and testis (Sun et al. 2020; Imai et al. 2005). A complex water-soluble drug designed by combining a macrocyclic molecule, Cyclodextrin with sACE2, which enhances the water solubility of the SACE2 for drug atomization inhalation. Cyclodextrin is linked by a pyran ring monosaccharide with the $\alpha$-1,4-glycoside bond and contains hydrophobic cavities (host), which encompasses hydrophobic molecules (guest molecules), resulting in a host-guest complex. After the administration into the body, the conjugate can release sACE2 that will combine with S-proteins of SARS-CoV-2, blocking the viral infection (Sun et al. 2020; Hong et al. 2009).

\section{Inhibitors targeting CD147}

CD147 has been observed to be the alternate route of entry of SARS-CoV-2. Azithromycin drug reduces the viral load in some patients. This might be a possibility that Azithromycin would interrupt the interactions of CD147 with ligand and suppress the expression of some metalloproteases that are downstream to CD147 (Ulrich and Pillat 2020). AntiCD147 Humanized Meplazumab (NCT04275245) uses monoclonal antibodies to block CD147 against SARS$\mathrm{CoV}-2$ infection and is also undergoing clinical trials in China. A tetracycline analog, Doxycycline decreases the 
expression of CD147 in gingival crevicular fluid in chronic periodontitis patients (Emingil et al. 2008), and gall-bladder carcinoma cell lines (He et al. 2017). Hence, these could also be effective in the treatment of SARS-CoV-2 infection in addition to other therapies.

\section{Serine and cysteine protease inhibitors targeting TMPRSS2, trypsin and cathepsin}

Cell line studies indicate the partial prevention of SARSCoV, HCoV-NL63 by serine protease inhibitor, Camostat in HeLa cell. Camostat also prevents the entry of MERS$\mathrm{CoV}$ in human Calu-3 bronchial submucosal gland cells (Shirato et al. 2013; Kawase et al. 2012). Similarly, SARSCoV-2 entry is prevented by Camostat mesylate that acts as a TMPRSS2 inhibitor (Hoffmann et al. 2020). Also, the Cathepsin inhibitor, MDL28170, prevents SARS-CoV (Simmons et al. 2005) and MERS-CoV (Gierer et al. 2013; Simmons et al. 2005; Huang et al. 2006) infection. Cysteine protease inhibitor like vinyl sulfones and K11777 ((2S)$\mathrm{N}$-[(1E,3S)-1-(benzenesulfonyl)-5-phenylpent-1-en-3-yl]2-\{[(E)-4-methylpiperazine-1-carbonyl]amino $\}-3$-phenylpropanamide) targets closely related vinyl sulfones to act as broad-spectrum antivirals by targeting cathepsin-mediated cell entry of Ebola and SARS-CoV (Zhou et al. 2015). These inhibitors could act on the human targets, preventing viral entry and pathogenesis.

\section{Conclusion}

The contagion SARS-CoV-2 had a significant impact on a global scale. However, it has a lower fatality rate with a higher transmissibility rate than SARS-CoV and MERSCoV. SARS-CoV-2 structure and genetic make-up are almost similar to all other coronaviruses, with few genetic alterations making it highly infectious (Petrosillo et al. 2020; Zhonghua et al. 2020; Kim et al. 2020; Lu et al. 2020). Likewise, SARS-CoV utilizes the ACE2 receptor for its entry and pathogenesis. Alternatively, it also uses CD147 and CD209L for infection, while MERS-CoV enters through DPP4 (Xu et al. 2020; Kim et al. 2020; Zhou et al. 2020a; Wang et al. 2020; Amraie et al. 2020). The infection through these receptors downregulates ACE2 expression upon virus binding and causes severe abnormalities in various tissues leading to critical conditions like ARDS and sepsis, later septic shock, and death (Peiris et al. 2003; Chen et al. 1998). ACE2 plays a vital role in the RAS system regulating Ang II levels, regulating heart function, and preventing fibrosis in the liver (Österreicher et al. 2009). The membrane-bound ACE2 is highly expressed in the heart, kidney, lungs, and GI tract (Turner et al. 2004; Chen et al. 2020). The ACE2 expression levels can be used as a molecular signature to determine the risk of infection in the body. Currently, the use of ACEi and ARBs against coronavirus infection is still under observation due to other side effects on comorbid patients. It could hence, be used for the treatment of COVID19 patients with mild or asymptomatic conditions. Since MSCs based therapy has a promising therapeutic effect, but the feasibility is low. Therefore, plasma therapy could also be used for initial treatments until proper vaccines and drugs are available. An alternative to plasma therapy uses of immune cells like monocytes, NK cells, B and T lymphocytes could be used for treatment. The enhancement of immune response by producing immune cells could prevent SARS-CoV-2 infection, thereby reducing COVID-19. The coronaviruses' entry is also mediated by other endogenous and membrane-bound proteases like TTSPs, furin, trypsin, elastase, thermolysin, PIKFYVE, and TPC2, depending upon the pathway of their entry and identifying inhibitors and blockers for these proteins would aid in the entry of the viruses. The viral domains involved during infection include the RBDs of $\mathrm{S} 1$ and $\mathrm{S} 2$ subunits, the $\mathrm{S} 1 / \mathrm{S} 2$ cleavage sites of MERS-CoV and SARS-CoV-2 (Xia et al. 2020; Tang et al. 2020 ), $6 \mathrm{HB}$ core structure, proteases like $3 \mathrm{CL}^{\mathrm{pro}} / \mathrm{M}^{\mathrm{pro}}$ and $\mathrm{PL}^{\mathrm{pro}}$ (Bosch et al. 2004). These domains will design potent antivirals, drugs, inhibitors, and vaccines against this contagion and control its infectivity and spread.

Acknowledgements This research received no external funding. Authors would like to acknowledge the open source repositories like PubMed, RCSB PDB (US), The Human Protein Atlas and GeneCards for providing informative data used in this study. This work has been performed by PKR and KK during their tenure at ICMR-NICPR.

Author contributions PKR designed research; PKR and KK performed research; PKR, KK, and DK wrote the paper; PKR, KK, and DK proofread the article.

\section{Declarations}

Conflicts of interest The authors declare no potential conflict of interest.

Research involving human participants and/or animals No human or animal studies have been used in this study.

Informed consent All figures are original, and no patient studies were involved; thus, no consent is required.

\section{References}

Aghai ZH, Kode A, Saslow JG, Nakhla T, Farhath S, Stahl GE et al (2007) Azithromycin suppresses activation of nuclear factorkappa B and synthesis of pro-inflammatory cytokines in tracheal aspirate cells from premature infants. Pediatr Res. https://doi.org/ 10.1203/PDR.0b013e318142582d 
Amraie R, Napoleon MA, Yin W, Berrigan J, Suder E, Zhao G et al (2020) CD209L/L-SIGN and CD209/DC-SIGN act as receptors for SARS-CoV-2 and are differentially expressed in lung and kidney epithelial and endothelial cells. BioRxiv Prepr Serv Biol. https://doi.org/10.1101/2020.06.22.165803

Anand P, Puranik A, Aravamudan M, Venkatakrishnan AJ, Soundararajan V (2020) SARS-CoV-2 strategically mimics proteolytic activation of human ENaC. Elife. https://doi.org/10.7554/eLife. 58603

Aoshiba K, Yokohori N, Nagai A (2003) Alveolar wall apoptosis causes lung destruction and emphysematous changes. Am J Respir Cell Mol Biol. https://doi.org/10.1165/rcmb.2002-0090OC

Arendse LB, Jan DAH, Poglitsch M, Touyz RM, Burnett JC, LlorensCortes $\mathrm{C}$ et al (2019) Novel therapeutic approaches targeting the renin-angiotensin system and associated peptides in hypertension and heart failure. Pharmacol Rev. https://doi.org/10.1124/ pr.118.017129

Armstrong J, Niemann H, Smeekens S, Rottier P, Warren G (1984) Sequence and topology of a model intracellular membrane protein, E1 glycoprotein, from a coronavirus. Nature. https://doi. org/10.1038/308751a0

Astuti IY (2020) Severe acute respiratory syndrome coronavirus 2 (SARS-CoV-2): an overview of viral structure and host response. Diabetes Metab Syndr Clin Res Rev. https://doi.org/10.1016/j. dsx.2020.04.020

Banales JM, Huebert RC, Karlsen T, Strazzabosco M, LaRusso NF, Gores GJ (2019) Cholangiocyte pathobiology. Nat Rev Gastroenterol Hepatol. https://doi.org/10.1038/s41575-019-0125-y

Bao W, Min D, Twigg SM, Shackel NA, Warner FJ, Yue DK et al (2010) Monocyte CD147 is induced by advanced glycation end products and high glucose concentration: possible role in diabetic complications. Am J Physiol Cell Physiol. https://doi.org/ 10.1152/ajpcell.00228.2010

Barkauskas CE, Cronce MJ, Rackley CR, Bowie EJ, Keene DR, Stripp BR et al (2013) Type 2 alveolar cells are stem cells in adult lung. J Clin Invest. https://doi.org/10.1172/JCI68782

Barragan M, Guillén JJ, Martin-Palomino N, Rodriguez A, Vassena R (2020) Undetectable viral RNA in oocytes from SARS-CoV-2 positive women. Hum Reprod. https://doi.org/10.1093/humrep/ deaa284

Beers MF, Moodley Y (2017) When is an alveolar type 2 cell an alveolar type 2 cell? A conundrum for lung stem cell biology and regenerative medicine. Am J Respir Cell Mol Biol. https://doi. org/10.1165/rcmb.2016-0426PS

Belouzard S, Chu VC, Whittaker GR (2009) Activation of the SARS coronavirus spike protein via sequential proteolytic cleavage at two distinct sites. Proc Natl Acad Sci USA. https://doi.org/10. 1073/pnas.0809524106

Belouzard S, Madu I, Whittaker GR (2010) Elastase-mediated activation of the severe acute respiratory syndrome coronavirus spike protein at discrete sites within the S2 domain. J Biol Chem. https://doi.org/10.1074/jbc.M110.103275

Bernardo ME, Fibbe WE (2013) Mesenchymal stromal cells: sensors and switchers of inflammation. Cell Stem Cell. https://doi.org/ 10.1016/j.stem.2013.09.006

Bertram S, Glowacka I, Blazejewska P, Soilleux E, Allen P, Danisch $S$ et al (2010) TMPRSS2 and TMPRSS4 facilitate trypsin-independent spread of influenza virus in Caco-2 cells. J Virol. https:// doi.org/10.1128/jvi.00239-10

Bertram S, Glowacka I, Muller MA, Lavender H, Gnirss K, Nehlmeier I et al (2011) Cleavage and activation of the severe acute respiratory syndrome coronavirus spike protein by human airway trypsin-like protease. J Virol. https://doi.org/10.1128/jvi. 05300-11

Bosch BJ, van der Zee R, de Haan CAM, Rottier PJM (2003) The coronavirus spike protein is a class I virus fusion protein: structural and functional characterization of the fusion core complex. J Virol. https://doi.org/10.1128/jvi.77.16.8801-8811.2003

Bosch BJ, Martina BEE, Van Der Zee R, Lepault J, Haijema BJ, Versluis $C$ et al (2004) Severe acute respiratory syndrome coronavirus (SARS-CoV) infection inhibition using spike protein heptad repeat-derived peptides. Proc Natl Acad Sci USA. https://doi.org/ 10.1073/pnas.0400576101

Böttcher E, Matrosovich T, Beyerle M, Klenk H-D, Garten W, Matrosovich M (2006) Proteolytic activation of influenza viruses by serine proteases TMPRSS2 and HAT from human airway epithelium. J Virol. https://doi.org/10.1128/jvi.01118-06

Brake SJ, Barnsley K, Lu W, McAlinden KD, Eapen MS, Sohal SS (2020) Smoking upregulates angiotensin-converting enzyme-2 receptor: a potential adhesion site for novel coronavirus SARSCoV-2 (COVID-19). J Clin Med. https://doi.org/10.3390/jcm90 30841

Burchill LJ, Velkoska E, Dean RG, Griggs K, Patel SK, Burrell LM (2012) Combination renin-angiotensin system blockade and angiotensin-converting enzyme 2 in experimental myocardial infarction: Implications for future therapeutic directions. Clin Sci. https://doi.org/10.1042/CS20120162

Canessa CM, Schild L, Buell G, Thorens B, Gautschi I, Horisberger JD et al (1994) Amiloride-sensitive epithelial Na+ channel is made of three homologous subunits. Nature. https://doi.org/10. $1038 / 367463 \mathrm{a} 0$

Chai X, Hu L, Zhang Y, Han W, Lu Z, Ke A et al (2020) Specific ACE2 expression in cholangiocytes may cause liver damage after 2019-nCoV infection. BioRxiv. https://doi.org/10.1101/2020.02. 03.931766

Chaipan C, Kobasa D, Bertram S, Glowacka I, Steffen I, Solomon TT et al (2009) Proteolytic activation of the 1918 influenza virus hemagglutinin. J Virol. https://doi.org/10.1128/jvi.02205-08

Chang CK, Sue SC, Yu TH, Hsieh CM, Tsai CK, Chiang YC et al (2006) Modular organization of SARS coronavirus nucleocapsid protein. J Biomed Sci. https://doi.org/10.1007/ s11373-005-9035-9

Chen XL, Tummala PE, Olbrych MT, Alexander RW, Medford RM (1998) Angiotensin II induces monocyte chemoattractant protein-1 gene expression in rat vascular smooth muscle cells. Circ Res. https://doi.org/10.1161/01.RES.83.9.952

Chen L, Li X, Chen M, Feng Y, Xiong C (2020) The ACE2 expression in human heart indicates new potential mechanism of heart injury among patients infected with SARS-CoV-2. Cardiovasc Res. https://doi.org/10.1093/cvr/cvaa078

Cheng H, Wang Y, Wang GQ (2020) Organ-protective effect of angiotensin-converting enzyme 2 and its effect on the prognosis of COVID-19. J Med Virol. https://doi.org/10.1002/jmv.25785

Cheung KS, Hung IFN, Chan PPY, Lung KC, Tso E, Liu R et al (2020) Gastrointestinal manifestations of SARS-CoV-2 infection and virus load in fecal samples from a Hong Kong cohort: systematic review and meta-analysis. Gastroenterology. https://doi.org/10. 1053/j.gastro.2020.03.065

Choi SY, Bertram S, Glowacka I, Park YW, Pöhlmann S (2009) Type II transmembrane serine proteases in cancer and viral infections. Trends Mol Med. https://doi.org/10.1016/j.molmed.2009.05.003

Clotet-Freixas S, Soler MJ, Palau V, Anguiano L, Gimeno J, Konvalinka A et al (2018) Sex dimorphism in ANGII-mediated crosstalk between ACE2 and ACE in diabetic nephropathy. Lab Investig. https://doi.org/10.1038/s41374-018-0084-X

Coutard B, Valle C, de Lamballerie X, Canard B, Seidah NG, Decroly E (2020) The spike glycoprotein of the new coronavirus 2019$\mathrm{nCoV}$ contains a furin-like cleavage site absent in $\mathrm{CoV}$ of the same clade. Antiviral Res. https://doi.org/10.1016/j.antiviral. 2020.104742 
Crackower MA, Sarao R, Oliveira-dos-Santos AJ, Da Costa J, Zhang L (2002) Angiotensin-converting enzyme 2 is an essential regulator of heart function. Nature. https://doi.org/10.1038/nature00786

Crosnier C, Bustamante LY, Bartholdson SJ, Bei AK, Theron M, Uchikawa $\mathrm{M}$ et al (2011) Basigin is a receptor essential for erythrocyte invasion by Plasmodium falciparum. Nature. https://doi.org/ 10.1038/nature 10606

Dahlöf B, Devereux RB, Kjeldsen SE, Julius S, Beevers G, De Faire U et al (2002) Cardiovascular morbidity and mortality in the Losartan Intervention For Endpoint reduction in hypertension study (LIFE): a randomised trial against atenolol. Lancet. https:// doi.org/10.1016/S0140-6736(02)08089-3

Dai L, Zheng T, Xu K, Han Y, Xu L, Huang E et al (2020) A universal design of betacoronavirus vaccines against COVID-19, MERS, and SARS. Cell. https://doi.org/10.1016/j.cell.2020.06.035

Danser AHJ, Epstein M, Batlle D (2020) Renin-angiotensin system blockers and the COVID-19 pandemic: at present there is no evidence to abandon renin-angiotensin system blockers. Hypertension. https://doi.org/10.1161/HYPERTENSIONAHA.120.15082

Derington CG, King JB, Herrick JS, Shimbo D, Kronish IM, Saseen JJ et al (2020) Trends in antihypertensive medication monotherapy and combination use among US adults, National health and Nutrition Examination Survey 2005-2016. Hypertension. https:// doi.org/10.1161/HYPERTENSIONAHA.119.14360

Effenberger M, Grabherr F, Mayr L, Schwaerzler J, Nairz M, Seifert M et al (2020) Faecal calprotectin indicates intestinal inflammation in COVID-19. Gut. https://doi.org/10.1136/gutjnl-2020-321388

Emingil G, Atilla G, Sorsa T, Tervahartiala T (2008) The effect of adjunctive subantimicrobial dose doxycycline therapy on GCF EMMPRIN levels in chronic periodontitis. J Periodontol. https:// doi.org/10.1902/jop.2008.070165

Fehr AR, Perlman S (2015) Coronaviruses: an overview of their replication and pathogenesis. Coronaviruses Methods Protoc. https:// doi.org/10.1007/978-1-4939-2438-7_1

Ferrario CM, Jessup J, Chappell MC, Averill DB, Brosnihan KB, Tallant EA et al (2005) Effect of angiotensin-converting enzyme inhibition and angiotensin II receptor blockers on cardiac angiotensin-converting enzyme 2. Circulation. https://doi.org/10.1161/ CIRCULATIONAHA.104.510461

Follis KE, York J, Nunberg JH (2006) Furin cleavage of the SARS coronavirus spike glycoprotein enhances cell-cell fusion but does not affect virion entry. Virology. https://doi.org/10.1016/j.virol. 2006.02.003

Gaillard EA, Kota P, Gentzsch M, Dokholyan NV, Stutts MJ, Tarran $\mathrm{R}$ (2010) Regulation of the epithelial $\mathrm{Na}+$ channel and airway surface liquid volume by serine proteases. Pflugers Arch Eur J Physiol. https://doi.org/10.1007/s00424-010-0827-z

Galipeau J, Sensébé L (2018) Mesenchymal stromal cells: clinical challenges and therapeutic opportunities. Cell Stem Cell. https://doi. org/10.1016/j.stem.2018.05.004

Ge XY, Li JL, Yang XL, Chmura AA, Zhu G, Epstein JH et al (2013) Isolation and characterization of a bat SARS-like coronavirus that uses the ACE2 receptor. Nature. https://doi.org/10.1038/ nature 12711

Gierer S, Bertram S, Kaup F, Wrensch F, Heurich A, Kramer-Kuhl A et al (2013) The spike protein of the emerging betacoronavirus EMC uses a novel coronavirus receptor for entry, can be activated by TMPRSS2, and is targeted by neutralizing antibodies. J Virol. https://doi.org/10.1128/jvi.00128-13

Goad J, Rudolph J, Rajkovic A (2020) Female reproductive tract has low concentration of SARS-CoV2 receptors. BioRxiv Prepr Serv Biol. https://doi.org/10.1101/2020.06.20.163097

Godet M, L'Haridon R, Vautherot JF, Laude H (1992) TGEV corona virus ORF4 encodes a membrane protein that is incorporated into virions. Virology. https://doi.org/10.1016/0042-6822(92) 90521-P
Golchin A (2020) Cell-based therapy for severe COVID-19 patients: clinical trials and cost-utility. Stem Cell Rev Rep. https://doi.org/ 10.1007/s12015-020-10046-1

Gomes CP, Fernandes DE, Casimiro F, da Mata GF, Passos MT, Varela $P$ et al (2020) Cathepsin L in COVID-19: from pharmacological evidences to genetics. Front Cell Infect Microbiol. https://doi. org/10.3389/fcimb.2020.589505

Gonzales JN, Lucas R, Verin AD (2015) The acute respiratory distress syndrome: mechanisms and perspective therapeutic approaches. Austin J Vasc Med. https://europepmc.org/articles/PMC4786180

Gorrell MD, Gysbers V, McCaughan GW (2001) CD26: a multifunctional integral membrane and secreted protein of activated lymphocytes. Scand J Immunol. https://doi.org/10.1046/j.1365-3083. 2001.00984.x

Groneberg DA, Hilgenfeld R, Zabel P (2005) Molecular mechanisms of severe acute respiratory syndrome (SARS). Respir Res. https:// doi.org/10.1186/1465-9921-6-8

Guan W-J, Ni Z-Y, Hu Y, Liang W-H, Ou C-Q, He J-X et al (2020) Clinical characteristics of coronavirus disease 2019 in China. N Engl J Med. https://doi.org/10.1056/nejmoa2002032

Guillot S, Delaval P, Brinchault G, Caulet-Maugendre S, Depince A, Lena $\mathrm{H}$ et al (2006) Increased extracellular matrix metalloproteinase inducer (EMMPRIN) expression in pulmonary fibrosis. Exp Lung Res. https://doi.org/10.1080/01902140600710512

Guo J, Huang Z, Lin L, Lv J (2020) Coronavirus disease 2019 (COVID19) and cardiovascular disease: a viewpoint on the potential influence of angiotensin-converting enzyme inhibitors/angiotensin receptor blockers on onset and severity of severe acute respiratory syndrome coronavirus 2 infec. J Am Heart Assoc. https://doi.org/10.1161/JAHA.120.016219

Gurka DP, Balk RA (2008) Acute respiratory failure, 3rd edn. Elsevier Inc., Philadelphia

Haber PK, Ye M, Wysocki J, Maier C, Haque SK, Batlle D (2014) Angiotensin-converting enzyme 2-independent action of presumed angiotensin-converting enzyme 2 activators: studies in vivo, ex vivo, and in vitro. Hypertension. https://doi.org/10. 1161/HYPERTENSIONAHA.113.02856

Hamming I, Timens W, Bulthuis MLC, Lely AT, Navis GJ, van Goor H (2004) Tissue distribution of ACE2 protein, the functional receptor for SARS coronavirus. A first step in understanding SARS pathogenesis. J Pathol. https://doi.org/10.1002/path.1570

Hanff TC, Harhay MO, Brown TS, Cohen JB, Mohareb AM (2020) Is there an association between COVID-19 mortality and the renin-angiotensin system-a call for epidemiologic investigations. Clin Infect Dis. https://doi.org/10.1093/cid/ciaa329

Hayes M, Curley G, Laffey JG (2012) Mesenchymal stem cellsa promising therapy for acute respiratory distress syndrome. F1000 Med Rep. https://doi.org/10.3410/M4-2

He H, Liu L, Chen Q, Liu A, Cai S, Yang Y et al (2015) Mesenchymal stem cells overexpressing angiotensin-converting enzyme 2 rescue lipopolysaccharide-induced lung injury. Cell Transpl. https://doi.org/10.3727/096368914X685087

He Q, Wang F, Honda T, Lindquist DM, Dillman JR, Timchenko NA et al (2017) Intravenous miR-144 inhibits tumor growth in diethylnitrosamine-induced hepatocellular carcinoma in mice. Tumor Biol. https://doi.org/10.1177/1010428317737729

Hilgenfeld R (2014) From SARS to MERS: crystallographic studies on coronaviral proteases enable antiviral drug design. FEBS J. https://doi.org/10.1111/febs.12936

Hoffmann M, Kleine-Weber H, Schroeder S, Krüger N, Herrler T, Erichsen S et al (2020) SARS-CoV-2 cell entry depends on ACE2 and TMPRSS2 and is blocked by a clinically proven protease inhibitor. Cell. https://doi.org/10.1016/j.cell.2020.02.052

Holshue ML, DeBolt C, Lindquist S, Lofy KH, Wiesman J, Bruce H et al (2020) First case of 2019 novel coronavirus in the United States. N Engl J Med. https://doi.org/10.1056/nejmoa2001191 
Hong PJ, Look DC, Tan P, Shi L, Hickey M, Gakhar L et al (2009) Ectodomain shedding of angiotensin converting enzyme 2 in human airway epithelia. Am J Physiol Lung Cell Mol Physiol. https://doi.org/10.1152/ajplung.00071.2009

Hu Y, Ma C, Szeto T, Hurst B, Tarbet B, Wang J (2020) Boceprevir, calpain inhibitors II and XII, and GC-376 have broad-spectrum antiviral activity against coronaviruses in cell culture. Bio Rxiv. https://doi.org/10.1101/2020.10.30.362335

Huang I-C, Bosch BJ, Li F, Li W, Kyoung HL, Ghiran S et al (2006) SARS coronavirus, but not human coronavirus NL63, utilizes cathepsin L to infect ACE2-expressing cells. J Biol Chem. https://doi.org/10.1074/jbc.M508381200

Huang C, Wang Y, Li X, Ren L, Zhao J, Hu Y et al (2020) Clinical features of patients infected with 2019 novel coronavirus in Wuhan, China. Lancet. https://doi.org/10.1016/S01406736(20)30183-5

Hurst KR, Koetzner CA, Masters PS (2009) Identification of in vivointeracting domains of the murine coronavirus nucleocapsid protein. J Virol. https://doi.org/10.1128/jvi.00440-09

Imai Y, Kuba K, Rao S, Huan Y, Guo F, Guan B et al (2005) Angiotensin-converting enzyme 2 protects from severe acute lung failure. Nature. https://doi.org/10.1038/nature03712

Inoue $\mathrm{Y}$, Tanaka N, Tanaka Y, Inoue S, Morita K, Zhuang M et al (2007) Clathrin-dependent entry of severe acute respiratory syndrome coronavirus into target cells expressing ACE2 with the cytoplasmic tail deleted. J Virol. https://doi.org/10.1128/jvi. 00253-07

Ishiyama Y, Gallagher PE, Averill DB, Tallant EA, Brosnihan KB, Ferrario CM (2004) Upregulation of angiotensin-converting enzyme 2 after myocardial infarction by blockade of angiotensin II receptors. Hypertension. https://doi.org/10.1161/01.HYP. $0000124667.34652 .1 \mathrm{a}$

Iwanami J, Mogi M, Tsukuda K, Wang XL, Nakaoka H, Ohshima K et al (2014) Role of angiotensin-converting enzyme 2/angiotensin-(1-7)/Mas axis in the hypotensive effect of azilsartan. Hypertens Res. https://doi.org/10.1038/hr.2014.49

Jaimes JA, Millet JK, Whittaker GR (2020) Proteolytic cleavage of the SARS-CoV-2 spike protein and the role of the novel S1/S2 site. IScience. https://doi.org/10.1016/j.isci.2020.101212

Jan SZ, Vormer TL, Jongejan A, Röling MD, Silber SJ, de Rooij DG et al (2017) Unraveling transcriptome dynamics in human spermatogenesis. Development. https://doi.org/10.1242/dev.152413

Jeffers SA, Tusell SM, Gillim-Ross L, Hemmila EM, Achenbach JE, Babcock GJ et al (2004) CD209L (L-SIGN) is a receptor for severe acute respiratory syndrome coronavirus. Proc Natl Acad Sci USA. https://doi.org/10.1073/pnas.0403812101

Jin Z, Du X, Xu Y, Deng Y, Liu M, Zhao Y et al (2020a) Structure of Mpro from SARS-CoV-2 and discovery of its inhibitors. Nature. https://doi.org/10.1038/s41586-020-2223-y

Jin X, Lian JS, Hu JH, Gao J, Zheng L, Zhang YM et al (2020b) Epidemiological, clinical and virological characteristics of 74 cases of coronavirus-infected disease 2019 (COVID-19) with gastrointestinal symptoms. Gut. https://doi.org/10.1136/ gutjnl-2020-320926

Kai H, Kai M (2020) Interactions of coronaviruses with ACE2, angiotensin II, and RAS inhibitors-lessons from available evidence and insights into COVID-19. Hypertens Res. https://doi.org/10. 1038/s41440-020-0455-8

Kam YW, Okumura Y, Kido H, Ng LFP, Bruzzone R, Altmeyer R (2009) Cleavage of the SARS coronavirus spike glycoprotein by airway proteases enhances virus entry into human bronchial epithelial cells in vitro. PLoS ONE. https://doi.org/10.1371/journ al.pone. 0007870

Kawaoka Y, Webster RG (1988) Sequence requirements for cleavage activation of influenza virus hemagglutinin expressed in mammalian cells. Proc Natl Acad Sci USA. https://doi.org/10. 1073/pnas.85.2.324

Kawase M, Shirato K, van der Hoek L, Taguchi F, Matsuyama S (2012) Simultaneous treatment of human bronchial epithelial cells with serine and cysteine protease inhibitors prevents severe acute respiratory syndrome coronavirus entry. J Virol. https://doi.org/10. 1128/jvi.00094-12

Khoury M, Cuenca J, Cruz FF, Figueroa FE, Rocco PRM, Weiss DJ (2020) Current status of cell-based therapies for respiratory virus infections: applicability to COVID-19. Eur Respir J. https://doi. org/10.1183/13993003.00858-2020

Kim Y, Lovell S, Tiew K-C, Mandadapu SR, Alliston KR, Battaile $\mathrm{KP}$ et al (2012) Broad-spectrum antivirals against 3C or 3C-like proteases of picornaviruses, noroviruses, and coronaviruses. J Virol. https://doi.org/10.1128/jvi.01348-12

Kim JM, Chung YS, Jo HJ, Lee NJ, Kim MS, Woo SH et al (2020) Identification of coronavirus isolated from a patient in Korea with COVID-19. Osong Public Heal Res Perspect. https://doi. org/10.24171/j.phrp.2020.11.1.02

Kleine-Weber H, Elzayat MT, Hoffmann M, Pöhlmann S (2018) Functional analysis of potential cleavage sites in the MERScoronavirus spike protein. Sci Rep. https://doi.org/10.1038/ s41598-018-34859-w

Krause DS, Theise ND, Collector MI, Henegariu O, Hwang S, Gardner $\mathrm{R}$ et al (2001) Multi-organ, multi-lineage engraftment by a single bone marrow-derived stem cell etic stem cells. Cell. https://doi. org/10.1016/S0092-8674(01)00328-2

Kuba K, Imai Y, Rao S, Gao H, Guo F, Guan B et al (2005) A crucial role of angiotensin converting enzyme 2 (ACE2) in SARS coronavirus-induced lung injury. Nat Med. https://doi.org/10. $1038 / \mathrm{nm} 1267$

Kumar S, Nyodu R, Maurya VK, Saxena SK (2020) Morphology, genome organization, replication, and pathogenesis of severe acute respiratory syndrome coronavirus 2 (SARS-CoV-2). Coronavirus Disease 2019 (COVID-19). https://doi.org/10.1007/ 978-981-15-4814-7_3

Lakshmanan AP, Thandavarayan RA, Watanabe K, Sari FR, Meilei H, Giridharan VV et al (2012) Modulation of AT-1R/MAPK cascade by an olmesartan treatment attenuates diabetic nephropathy in streptozotocin-induced diabetic mice. Mol Cell Endocrinol 348(1):104-111. https://doi.org/10.1016/j.mce.2011.07.041

Lan J, Ge J, Yu J, Shan S, Zhou H, Fan S et al (2020) Structure of the SARS-CoV-2 spike receptor-binding domain bound to the ACE2 receptor. Nature. https://doi.org/10.1038/s41586-020-2180-5

Lau SKP, Li KSM, Tsang AKL, Lam CSF, Ahmed S, Chen H et al (2013) Genetic characterization of betacoronavirus lineage C viruses in bats reveals marked sequence divergence in the spike protein of Pipistrellus bat coronavirus HKU5 in Japanese Pipistrelle: implications for the origin of the Novel Middle East Respiratory Sy. J Virol. https://doi.org/10.1128/jvi.01055-13

Leng Z, Zhu R, Hou W, Feng Y, Yang Y, Han Q et al (2020) Transplantation of ACE2-mesenchymal stem cells improves the outcome of patients with COVID-19 pneumonia. Aging Dis. https://doi. org/10.14336/AD.2020.0228

Li W, Moore MJ, Vasllieva N, Sui J, Wong SK, Berne MA et al (2003) Angiotensin-converting enzyme 2 is a functional receptor for the SARS coronavirus. Nature. https://doi.org/10.1038/nature02145

Li J, Gao J, Xu Y-P, Zhou T-L, Jin Y-Y, Lou J-N (2007) Expression of severe acute respiratory syndrome coronavirus receptors, ACE2 and CD209L in different organ derived microvascular endothelial cells. Natl Med J China. https://doi.org/10.3760/j:issn:03762491.2007.12.013

Li J, Li D, Liu X, Tang S, Wei F (2012) Human umbilical cord mesenchymal stem cells reduce systemic inflammation and attenuate LPS-induced acute lung injury in rats. J Inflamm (UK). https:// doi.org/10.1186/1476-9255-9-33 
Li XC, Zhang J, Zhuo JL (2017) The vasoprotective axes of the reninangiotensin system: physiological relevance and therapeutic implications in cardiovascular, hypertensive and kidney diseases. Pharmacol Res. https://doi.org/10.1016/j.phrs.2017.06.005

Li D, Jin M, Bao P, Zhao W, Zhang S (2020) Clinical characteristics and results of semen tests among men with coronavirus disease 2019. JAMA Netw Open. https://doi.org/10.1001/jamanetwor kopen. 2020.8292

Lin L, Jiang X, Zhang Z, Huang S, Zhang Z, Fang Z et al (2020) Gastrointestinal symptoms of 95 cases with SARS-CoV-2 infection. Gut. https://doi.org/10.1136/gutjnl-2020-321013

Lindholm LH, Ibsen H, Dahlöf B, Devereux RB, Beevers G, De Faire $\mathrm{U}$ et al (2002) Cardiovascular morbidity and mortality in patients with diabetes in the Losartan Intervention For Endpoint reduction in hypertension study (LIFE): a randomised trial against atenolol. Lancet. https://doi.org/10.1016/S0140-6736(02)08090-X

Liu S, Zheng Q, Wang Z (2020a) Potential covalent drugs targeting the main protease of the SARS-CoV-2 coronavirus. Bioinformatics. https://doi.org/10.1093/bioinformatics/btaa224

Liu Z, Xiao X, Wei X, Li J, Yang J, Tan H et al (2020b) Composition and divergence of coronavirus spike proteins and host ACE2 receptors predict potential intermediate hosts of SARS-CoV-2. J Med Virol. https://doi.org/10.1002/jmv.25726

Liu J, Li S, Liu J, Liang B, Wang X, Wang H et al (2020c) Longitudinal characteristics of lymphocyte responses and cytokine profiles in the peripheral blood of SARS-CoV-2 infected patients. EBioMedicine. https://doi.org/10.1016/j.ebiom.2020.102763

Lu R, Zhao X, Li J, Niu P, Yang B, Wu H et al (2020) Genomic characterisation and epidemiology of 2019 novel coronavirus: implications for virus origins and receptor binding. Lancet. https://doi. org/10.1016/S0140-6736(20)30251-8

Lucas JM, Heinlein C, Kim T, Hernandez SA, Malik MS, True LD et al (2014) The androgen-regulated protease TMPRSS2 activates a proteolytic cascade involving components of the tumor microenvironment and promotes prostate cancer metastasis. Cancer Discov. https://doi.org/10.1158/2159-8290.CD-13-1010

Ma C, Sacco MD, Hurst B, Townsend JA, Hu Y, Szeto T et al (2020a) Boceprevir, GC-376, and calpain inhibitors II, XII inhibit SARSCoV-2 viral replication by targeting the viral main protease. Cell Res. https://doi.org/10.1038/s41422-020-0356-z

Ma C, Cong Y, Zhang H (2020b) COVID-19 and the digestive system. Am J Gastroenterol. https://doi.org/10.14309/ajg.0000000000 000691

Magrone T, Magrone M, Jirillo E (2020) Focus on receptors for coronaviruses with special reference to angiotensin-converting enzyme 2 as a potential drug target-a perspective. Endocr Metab Immune Disord Drug Targets. https://doi.org/10.2174/ 1871530320666200427112902

Malaiyan J, Arumugam S, Mohan K, Gomathi RG (2020) An update on the origin of SARS-CoV-2: despite closest identity, bat (RaTG13) and pangolin derived coronaviruses varied in the critical binding site and O-linked glycan residues. J Med Virol. https://doi.org/10.1002/jmv.26261

Malik YS, Sircar S, Bhat S, Sharun K, Dhama K, Dadar M et al (2020) Emerging novel coronavirus (2019-nCoV)—current scenario, evolutionary perspective based on genome analysis and recent developments. Vet Q. https://doi.org/10.1080/01652176.2020. 1727993

Mann JFE, Schmieder RE, McQueen M, Dyal L, Schumacher H, Pogue J et al (2008) Renal outcomes with telmisartan, ramipril, or both, in people at high vascular risk (the ONTARGET study): a multicentre, randomised, double-blind, controlled trial. Lancet 372(9638):547-553. https://doi.org/10.1016/S0140-6736(08) 61236-2
Mason RJ, Dobbs LG (1980) Synthesis of phosphatidylcholine and phosphatidylglycerol by alveolar type II cells in primary culture. J Biol Chem. https://doi.org/10.1016/s0021-9258(19)70755-8

Masters PS (2006) The molecular biology of coronaviruses. Adv Virus Res. https://doi.org/10.1016/S0065-3527(06)66005-3

Matsuyama S, Ujike M, Morikawa S, Tashiro M, Taguchi F (2005) Protease-mediated enhancement of severe acute respiratory syndrome coronavirus infection. Proc Natl Acad Sci USA. https:// doi.org/10.1073/pnas.0503203102

Matsuyama S, Nagata N, Shirato K, Kawase M, Takeda M, Taguchi F (2010) Efficient activation of the severe acute respiratory syndrome coronavirus spike protein by the transmembrane protease TMPRSS2. J Virol. https://doi.org/10.1128/jvi.01542-10

Matsuyama S, Nao N, Shirato K, Kawase M, Saito S, Takayama I et al (2020) Enhanced isolation of SARS-CoV-2 by TMPRSS2expressing cells. Proc Natl Acad Sci USA. https://doi.org/10. 1073/pnas.2002589117

Mattos W, Lim S, Russell R, Jatakanon A, Chung KF, Barnes PJ (2002) Matrix metalloproteinase-9 expression in asthma: effect of asthma severity, allergen challenge, and inhaled corticosteroids. Chest. https://doi.org/10.1378/chest.122.5.1543

McMurray JJV, Östergren J, Swedberg K, Granger CB, Held P, Michelson EL et al (2003) Effects of candesartan in patients with chronic heart failure and reduced left-ventricular systolic function taking angiotensin-converting-enzyme inhibitors: the CHARM-added trial. Lancet. https://doi.org/10.1016/S01406736(03)14283-3

Memish ZA, Perlman S, Van Kerkhove MD, Zumla A (2020) Middle East respiratory syndrome. Lancet. https://doi.org/10.1016/ S0140-6736(19)33221-0

Mille JK, Whittaker GR (2014) Host cell entry of Middle East respiratory syndrome coronavirus after two-step, furin-mediated activation of the spike protein. Proc Natl Acad Sci USA. https://doi. org/10.1073/pnas.1407087111

Miller AJ, Arnold AC (2019) The renin-angiotensin system in cardiovascular autonomic control: recent developments and clinical implications. Clin Auton Res. https://doi.org/10.1007/ s10286-018-0572-5

Min F, Gao F, Li Q, Liu Z (2015) Therapeutic effect of human umbilical cord mesenchymal stem cells modifed by angiotensinconverting enzyme 2 gene on bleomycin-induced lung fibrosis injury. Mol Med Rep. https://doi.org/10.3892/mmr.2014.3025

Moheimani F, Koops J, Williams T, Reid AT, Hansbro PM, Wark PA et al (2018) Influenza A virus infection dysregulates the expression of microRNA-22 and its targets; CD147 and HDAC4, in epithelium of asthmatics. Respir Res. https://doi.org/10.1186/ s12931-018-0851-7

Nicin L, Abplanalp WT, Mellentin H, Kattih B, Tombor L, John D et al (2020) Cell type-specific expression of the putative SARS-CoV-2 receptor ACE2 in human hearts. Eur Heart J. https://doi.org/10. 1093/eurheartj/ehaa311

Nieto-Torres JL, DeDiego ML, Verdiá-Báguena C, Jimenez-Guardeño JM, Regla-Nava JA, Fernandez-Delgado R et al (2014) Severe acute respiratory syndrome coronavirus envelope protein ion channel activity promotes virus fitness and pathogenesis. PLoS Pathog. https://doi.org/10.1371/journal.ppat.1004077

Nobel YR, Phipps M, Zucker J, Lebwohl B, Wang TC, Sobieszczyk ME et al (2020) Gastrointestinal symptoms and coronavirus disease 2019: a case-control study from the United States. Gastroenterology. https://doi.org/10.1053/j.gastro.2020.04.017

Nutho B, Mahalapbutr P, Hengphasatporn K, Pattaranggoon NC, Simanon N, Shigeta Y et al (2020) Why are lopinavir and ritonavir effective against the newly emerged coronavirus 2019 ? Atomistic insights into the inhibitory mechanisms. Biochemistry. https://doi.org/10.1021/acs.biochem.0c00160 
Ortiz-Melo DI, Gurley SB (2016) Angiotensin converting enzyme 2 and the kidney. Curr Opin Nephrol Hypertens. https://doi.org/10. 1097/MNH.0000000000000182

Österreicher CH, Taura K, De Minicis S, Seki E, Penz-Österreicher $\mathrm{M}$, Kodama $\mathrm{Y}$ et al (2009) Angiotensin-converting-enzyme 2 inhibits liver fibrosis in mice. Hepatology. https://doi.org/10. 1002/hep.23104

Ou X, Liu Y, Lei X, Li P, Mi D, Ren L et al (2020) Characterization of spike glycoprotein of SARS-CoV-2 on virus entry and its immune cross-reactivity with SARS-CoV. Nat Commun. https:// doi.org/10.1038/s41467-020-15562-9

Pan L, Mu M, Yang P, Sun Y, Wang R, Yan J et al (2020) Clinical characteristics of COVID-19 patients with digestive symptoms in Hubei, China: a descriptive, cross-sectional, multicenter study. Am J Gastroenterol. https://doi.org/10.14309/ajg.0000000000 000620

Parks JM, Smith JC (2020) How to discover antiviral drugs quickly. N Engl J Med. https://doi.org/10.1056/NEJMcibr2007042

Patel SK, Velkoska E, Freeman M, Wai B, Lancefield TF, Burrell LM (2014) From gene to protein-experimental and clinical studies of ACE2 in blood pressure control and arterial hypertension. Front Physiol. https://doi.org/10.3389/fphys.2014.00227

Peiris JSM, Lai ST, Poon LLM, Guan Y, Yam LYC, Lim W et al (2003) Coronavirus as a possible cause of severe acute respiratory syndrome. Lancet. https://doi.org/10.1016/S0140-6736(03)13077-2

Pérez-Gil J (2008) Structure of pulmonary surfactant membranes and films: the role of proteins and lipid-protein interactions. Biochim Biophys Acta Biomembr. https://doi.org/10.1016/j.bbamem. 2008.05.003

Petrosillo N, Viceconte G, Ergonul O, Ippolito G, Petersen E (2020) COVID-19, SARS and MERS: are they closely related? Clin Microbiol Infect. https://doi.org/10.1016/j.cmi.2020.03.026

Pinto BGG, Oliveira AER, Singh Y, Jimenez L, Gonçalves ANA, Ogava RLT et al (2020) ACE2 expression is increased in the lungs of patients with comorbidities associated with severe COVID-19. J Infect Dis. https://doi.org/10.1093/infdis/jiaa332

Pišlar A, Mitrovic A, Sabotič J, Fonovic UP, Nanut MP, Jakoš T et al (2020) The role of cysteine peptidases in coronavirus cell entry and replication: the therapeutic potential of cathepsin inhibitors. PLoS Pathog. https://doi.org/10.1371/journal.ppat.1009013

Pitt B, Poole-Wilson PA, Segal R, Martinez FA, Dickstein K, Camm AJ et al (2000) Effect of losartan compared with captopril on mortality in patients with symptomatic heart failure: randomised trial-the Losartan Heart Failure Survival Study ELITE II. Lancet. https://doi.org/10.1016/S0140-6736(00)02213-3

Qian Z, Dominguez SR, Holmes KV (2013) Role of the spike glycoprotein of human middle east respiratory syndrome coronavirus (MERS-CoV) in virus entry and syncytia formation. PLoS ONE. https://doi.org/10.1371/journal.pone.0076469

Qiu Z, Hingley ST, Simmons G, Yu C, Sarma JD, Bates P et al (2006) Endosomal proteolysis by cathepsins is necessary for murine coronavirus mouse hepatitis virus type 2 spike-mediated entry. $\mathrm{J}$ Virol. https://doi.org/10.1128/JVI.00442-06

Raj VS, Mou H, Smits SL, Dekkers DHW, Müller MA, Dijkman R et al (2013) Dipeptidyl peptidase 4 is a functional receptor for the emerging human coronavirus-EMC. Nature. https://doi.org/ 10.1038 /nature 12005

Ramadan N, Shaib H (2019) Middle east respiratory syndrome coronavirus (MERS-COV): a review. GERMS. https://doi.org/10. 18683/germs.2019.1155

Redd WD, Zhou JC, Hathorn KE, McCarty TR, Bazarbashi AN, Thompson CC et al (2020) Prevalence and characteristics of gastrointestinal symptoms in patients with severe acute respiratory syndrome coronavirus 2 infection in the United States: a multicenter cohort study. Gastroenterology. https://doi.org/10. 1053/j.gastro.2020.04.045

Regan AD, Shraybman R, Cohen RD, Whittaker GR (2008) Differential role for low $\mathrm{pH}$ and cathepsin-mediated cleavage of the viral spike protein during entry of serotype II feline coronaviruses. Vet Microbiol. https://doi.org/10.1016/j.vetmic.2008.05.019

Rivellese F, Prediletto E (2020) ACE2 at the centre of COVID-19 from paucisymptomatic infections to severe pneumonia. Autoimmun Rev. https://doi.org/10.1016/j.autrev.2020.102536

Rossier BC, Stutts MJ (2009) Activation of the epithelial sodium channel $(\mathrm{ENaC})$ by serine proteases. Annu Rev Physiol. https://doi. org/10.1146/annurev.physiol.010908.163108

Sacco MD, Ma C, Lagarias P, Gao A, Townsend JA, Meng X et al (2020) Structure and inhibition of the SARS-CoV-2 main protease reveals strategy for developing dual inhibitors against $\mathrm{M}$ pro and cathepsin L. Sci Adv. https://doi.org/10.1126/sciadv. abe 0751

Santos RAS, Sampaio WO, Alzamora AC, Motta-Santos D, Alenina N, Bader $M$ et al (2018) The ACE2/angiotensin-(1-7)/Mas axis of the renin-angiotensin system: focus on angiotensin-(1-7). Physiol Rev. https://doi.org/10.1152/physrev.00023.2016

Segars J, Katler Q, McQueen DB, Kotlyar A, Glenn T, Knight Z et al (2020) Prior and novel coronaviruses, Coronavirus Disease 2019 (COVID-19), and human reproduction: what is known? Fertil Steril. https://doi.org/10.1016/j.fertnstert.2020.04.025

Seidah NG, Chretien M (1999) Proprotein and prohormone convertases: a family of subtilases generating diverse bioactive polypeptides. Brain Res. https://doi.org/10.1016/S0006-8993(99) 01909-5

Serfozo P, Wysocki J, Gulua G, Schulze A, Ye M, Liu P et al (2020) Ang II (angiotensin II) conversion to Angiotensin-(1-7) in the circulation is POP (prolyloligopeptidase)-dependent and ACE2 (angiotensin-converting enzyme 2)-independent. Hypertens (Dallas, Tex 1979) 75(1):173-182. https://doi.org/10.1161/HYPER TENSIONAHA.119.14071

Shirato K, Kawase M, Matsuyama S (2013) Middle east respiratory syndrome coronavirus infection mediated by the transmembrane serine protease TMPRSS2. J Virol. https://doi.org/10.1128/JVI. 01890-13

Simmons G, Reeves JD, Rennekamp AJ, Amberg SM, Piefer AJ, Bates P (2004) Characterization of severe acute respiratory syndromeassociated coronavirus (SARS-CoV) spike glycoprotein-mediated viral entry. Proc Natl Acad Sci USA. https://doi.org/10. 1073/pnas.0306446101

Simmons G, Gosalia DN, Rennekamp AJ, Reeves JD, Diamond SL, Bates P (2005) Inhibitors of cathepsin L prevent severe acute respiratory syndrome coronavirus entry. Proc Natl Acad Sci USA. https://doi.org/10.1073/pnas.0505577102

Sparks MA, South A, Welling P, Mattluther J, Cohen J, Byrd JB et al (2020) Sound science before quick judgement regarding RAS blockade in COVID-19. Clin J Am Soc Nephrol. https://doi.org/ 10.2215/CJN.03530320

Sukumaran V, Veeraveedu PT, Gurusamy N, Yamaguchi K, Lakshmanan AP, Ma M et al (2011) Cardioprotective effects of telmisartan against heart failure in rats in-duced by experimental autoimmune myocarditis through the modulation of AngiotensinConverting Enzyme-2/Angiotensin 1-7/Mas Receptor axis. Int J Biol Sci. https://doi.org/10.7150/ijbs.7.1077

Sukumaran V, Veeraveedu PT, Lakshmanan AP, Gurusamy N, Yamaguchi K, Ma M et al (2012a) Olmesartan medoxomil treatment potently improves cardiac myosin-induced dilated cardiomyopathy via the modulation of ACE-2 and ANG 17 mas receptor. Free Radic Res. https://doi.org/10.3109/10715762.2012.684878

Sukumaran V, Veeraveedu PT, Gurusamy N, Lakshmanan AP, Yamaguchi K, Ma M et al (2012b) Olmesartan attenuates the 
development of heart failure after experimental autoimmune myocarditis in rats through the modulation of ANG 1-7 mas receptor. Mol Cell Endocrinol. https://doi.org/10.1016/j.mce. 2011.12.010

Sukumaran V, Tsuchimochi H, Tatsumi E, Shirai M, Pearson JT (2017) Azilsartan ameliorates diabetic cardiomyopathy in young $\mathrm{db} / \mathrm{db}$ mice through the modulation of ACE-2/ANG 1-7/Mas receptor cascade. Biochem Pharmacol. https://doi.org/10.1016/j.bcp. 2017.07.022

Sun P, Lu X, Xu C, Wang Y, Sun W, Xi J (2020) CD-sACE2 inclusion compounds: an effective treatment for coronavirus disease 2019 (COVID-19). J Med Virol. https://doi.org/10.1002/jmv.25804

Tai W, He L, Zhang X, Pu J, Voronin D, Jiang S et al (2020) Characterization of the receptor-binding domain (RBD) of 2019 novel coronavirus: implication for development of RBD protein as a viral attachment inhibitor and vaccine. Cell Mol Immunol. https://doi. org/10.1038/s41423-020-0400-4

Talreja H, Tan J, Dawes, M, Supershad S, Rabindranath K, Fisher J et al (2020) A consensus statement on the use of angiotensin receptor blockers and angiotensin converting enzyme inhibitors in relation to COVID-19 (corona virus disease 2019). NZ Med J

Tang T, Bidon M, Jaimes JA, Whittaker GR, Daniel S (2020) Coronavirus membrane fusion mechanism offers a potential target for antiviral development. Antiviral Res. https://doi.org/10.1016/j. antiviral.2020.104792

Tarjus A, Maase M, Jeggle P, Martinez-Martinez E, Fassot C, Loufrani $\mathrm{L}$ et al (2017) The endothelial $\alpha \mathrm{ENaC}$ contributes to vascular endothelial function in vivo. PLoS ONE. https://doi.org/10.1371/ journal.pone.0185319

Tikellis C, Bernardi S, Burns WC (2011) Angiotensin-converting enzyme 2 is a key modulator of the renin-angiotensin system in cardiovascular and renal disease. Curr Opin Nephrol Hypertens. https://doi.org/10.1097/MNH.0b013e328341164a

Trottein F, Sokol H (2020) Potential causes and consequences of gastrointestinal disorders during a SARS-CoV-2 infection. Cell Rep. https://doi.org/10.1016/j.celrep.2020.107915

Turner AJ, Hiscox JA, Hooper NM (2004) ACE2: from vasopeptidase to SARS virus receptor. Trends Pharmacol Sci. https://doi.org/ 10.1016/j.tips.2004.04.001

Uhlen M, Zhang C, Lee S, Sjöstedt E, Fagerberg L, Bidkhori G et al (2017) A pathology atlas of the human cancer transcriptome. Science (80-). https://doi.org/10.1126/science.aan2507

Ulrich H, Pillat MM (2020) CD147 as a target for COVID-19 treatment: suggested effects of azithromycin and stem cell engagement. Stem Cell Rev Rep. https://doi.org/10.1007/s12015-020-09976-7

Vickers C, Hales P, Kaushik V, Dick L, Gavin J, Tang J et al (2002) Hydrolysis of biological peptides by human angiotensin-converting enzyme-related carboxypeptidase. J Biol Chem. https://doi. org/10.1074/jbc.M200581200

Vishvkarma R, Rajender S (2020) Could SARS-CoV-2 affect male fertility? Andrologia. https://doi.org/10.1111/and.13712

Vuille-Dit-Bille RN, Camargo SM, Emmenegger L, Sasse T, Kummer E, Jando J et al (2015) Human intestine luminal ACE2 and amino acid transporter expression increased by ACE-inhibitors. Amino Acids. https://doi.org/10.1007/s00726-014-1889-6

Walls AC, Park YJ, Tortorici MA, Wall A, McGuire AT, Veesler D (2020) Structure, function, and antigenicity of the SARS-CoV-2 spike glycoprotein. Cell. https://doi.org/10.1016/j.cell.2020.02. 058

Wan Y, Shang J, Graham R, Baric RS, Li F (2020) Receptor recognition by the novel coronavirus from Wuhan: an analysis based on decade-long structural studies of SARS coronavirus. J Virol. https://doi.org/10.1128/jvi.00127-20

Wang H, Yang P, Liu K, Guo F, Zhang Y, Zhang G et al (2008) SARS coronavirus entry into host cells through a novel clathrin- and caveolae-independent endocytic pathway. Cell Res. https://doi. org/10.1038/cr.2008.15

Wang N, Shi X, Jiang L, Zhang S, Wang D, Tong P et al (2013) Structure of MERS-CoV spike receptor-binding domain complexed with human receptor DPP4. Cell Res. https://doi.org/10.1038/ cr.2013.92

Wang Q, Qi J, Yuan Y, Xuan Y, Han P, Wan Y et al (2014) Bat origins of MERS-CoV supported by bat coronavirus HKU4 usage of human receptor CD26. Cell Host Microbe. https://doi.org/10. 1016/j.chom.2014.08.009

Wang C, Li W, Drabek D, Okba NMA, van Haperen R, Osterhaus ADME et al (2020a) A human monoclonal antibody blocking SARS-CoV-2 infection. Nat Commun. https://doi.org/10.1038/ s41467-020-16256-y

Wang K, Chen W, Zhou Y-S, Lian J-Q, Zhang Z, Du P et al (2020b) SARS-CoV-2 invades host cells via a novel route: CD147-spike protein. BioRxiv. https://doi.org/10.1101/2020.03.14.988345

Wang W, Xu Y, Gao R, Lu R, Han K, Wu G et al (2020c) Detection of SARS-CoV-2 in different types of clinical specimens. JAMA J Am Med Assoc. https://doi.org/10.1001/jama.2020.3786

Wang D, Hu B, Hu C, Zhu F, Liu X, Zhang J et al (2020d) Clinical characteristics of 138 hospitalized patients with 2019 novel coronavirus-infected pneumonia in Wuhan, China. JAMA J Am Med Assoc. https://doi.org/10.1001/jama.2020.1585

Wang N, Shang J, Jiang S, Du L (2020e) Subunit vaccines against emerging pathogenic human coronaviruses. Front Microbiol. https://doi.org/10.3389/fmicb.2020.00298

Ware LB, Matthay MA (2000) The acute respiratory distress syndrome. N Engl J Med. https://doi.org/10.1056/NEJM200005043421806

Wong SK, Li W, Moore MJ, Choe H, Farzan M (2004) A 193-amino acid fragment of the SARS coronavirus S protein efficiently binds angiotensin-converting enzyme 2. J Biol Chem. https://doi.org/ 10.1074/jbc.C300520200

Wrapp D, Wang N, Corbett KS, Goldsmith JA, Hsieh C-L, Abiona O et al (2020) Cryo-EM structure of the 2019-nCoV spike in the prefusion conformation. Science (80-). https://doi.org/10.1126/ science.aax0902

Wu A, Peng Y, Huang B, Ding X, Wang X, Niu P et al (2020) Genome composition and divergence of the novel coronavirus (2019nCoV) originating in China. Cell Host Microbe. https://doi.org/ 10.1016/j.chom.2020.02.001

Xia S, Liu M, Wang C, Xu W, Lan Q, Feng S et al (2020) Inhibition of SARS-CoV-2 (previously 2019-nCoV) infection by a highly potent pan-coronavirus fusion inhibitor targeting its spike protein that harbors a high capacity to mediate membrane fusion. Cell Res. https://doi.org/10.1038/s41422-020-0305-x

Xu J, Sriramula S, Xia H, Moreno-Walton L, Culicchia F, Domenig O et al (2017) Clinical relevance and role of neuronal AT1 receptors in ADAM17-mediated ACE2 shedding in neurogenic hypertension. Circ Res. https://doi.org/10.1161/CIRCRESAHA.116. 310509

Xu L, Liu J, Lu M, Yang D, Zheng X (2020) Liver injury during highly pathogenic human coronavirus infections. Liver Int. https://doi. org/10.1111/liv.14435

Xudong X, Junzhu C, Xingxiang W, Furong Z, Yanrong L (2006) Ageand gender-related difference of ACE2 expression in rat lung. Life Sci. https://doi.org/10.1016/j.lfs.2005.09.038

Yuan Y, Cao D, Zhang Y, Ma J, Qi J, Wang Q et al (2017) Cryo-EM structures of MERS-CoV and SARS-CoV spike glycoproteins reveal the dynamic receptor binding domains. Nat Commun. https://doi.org/10.1038/ncomms15092

Zhang L, Lin D, Sun X, Curth U, Drosten C, Sauerhering L et al (2020a) Crystal structure of SARS-CoV-2 main protease provides a basis for design of improved a-ketoamide inhibitors. Science (80-). https://doi.org/10.1126/science.abb3405 
Zhang L, Liu J, Cao R, Xu M, Wu Y, Shang W et al (2020b) Comparative antiviral efficacy of viral protease inhibitors against the novel SARS-CoV-2 in vitro. Virol Sin. https://doi.org/10.1007/ s12250-020-00288-1

Zhang B, Liu S, Tan T, Huang W, Dong Y, Chen L et al (2020c) Treatment with convalescent plasma for critically ill patients with severe acute respiratory syndrome coronavirus 2 infection. Chest. https://doi.org/10.1016/j.chest.2020.03.039

Zheng YY, Ma YT, Zhang JY, Xie X (2020) COVID-19 and the cardiovascular system. Nat Rev Cardiol. https://doi.org/10.1038/ s41569-020-0360-5

Zhonghua L, Xing BX, Za ZZ, Liuxingbingxue Z (2020) The epidemiological characteristics of an outbreak of 2019 novel coronavirus diseases (COVID-19) in China. Chin J Epidemiol. https://doi.org/ 10.3760/cma.j.issn.0254-6450.2020.02.003

Zhou Y, Vedantham P, Lu K, Agudelo J, Carrion R, Nunneley JW et al (2015) Protease inhibitors targeting coronavirus and filovirus entry. Antiviral Res. https://doi.org/10.1016/j.antiviral.2015. 01.011

Zhou P, Yang X-L, Wang X-G, Hu B, Zhang L, Zhang W et al (2020a) A pneumonia outbreak associated with a new coronavirus of probable bat origin. Nature. https://doi.org/10. 1038/s41586-020-2012-7

Zhou Z, Zhao N, Shu Y, Han S, Chen B, Shu X (2020b) Effect of gastrointestinal symptoms in patients with COVID-19. Gastroenterology. https://doi.org/10.1053/j.gastro.2020.03.020

Zmora P, Hoffmann M, Kollmus H, Moldenhauer AS, Danov O, Braun A et al (2018) TMPRSS11A activates the influenza A virus hemagglutinin and the MERS coronavirus spike protein and is insensitive against blockade by HAI-1. J Biol Chem. https://doi. org/10.1074/jbc.RA118.001273

Zumla A, Chan JFW, Azhar EI, Hui DSC, Yuen KY (2016) Coronaviruses-drug discovery and therapeutic options. Nat Rev Drug Discov. https://doi.org/10.1038/nrd.2015.37

Publisher's Note Springer Nature remains neutral with regard to jurisdictional claims in published maps and institutional affiliations. 